Chapter 4

\title{
Molecular Tools for Understanding Eco-Epidemiology, Diversity and Pathogenesis of Leishmania Parasites
}

\author{
Souheila Guerbouj, Imen Mkada-Driss and \\ Ikram Guizani \\ Additional information is available at the end of the chapter \\ http://dx.doi.org/10.5772/57510
}

\section{Introduction}

Protozoan parasites of the genus Leishmania are responsible of a large variety of clinical manifestations ranging from self-healing cutaneous forms (CL), through mucocutaneous lesions (MCL), to lethal if untreated visceral disease (VL). Nevertheless, there is no absolute correlation between a particular clinical form and a causative species [1]. For instance, parasites of the L. donovani complex are generally responsible for VL cases in the Old and New World but can also cause CL. Another example is the L. tropica species, which causes a CL form but its association to VL cases was occasionally reported [2]. Identification of Leishmania parasites is a central issue to patients' management and to control. Leishmaniases have a worldwide distribution but only absent in the poles regions, and in Australia where in spite of presence of the parasites in Kangourous no human cases were described. According to the WHO, 350 million people are at risk, with a prevalence of 12 million and more than 98 countries affected [3]. More than twenty species are responsible for leishmaniasis in humans. However, Leishmania species present very similar morphologies in their flagellated, promastigote forms and their intracellular, amastigote forms which renders necessary the use of molecular or biochemical assays for their identification and characterization (see for review [4]).

The current identification and classification of Leishmania is still based on isoenzyme typing, using multilocus enzyme electrophoresis (MLEE) (reviewed in [5]). This approach has been widely used for the identification of Leishmania, but several limitations were reported. Most importantly, differences in electrophoretic profiles were shown to be due to heterozygosity at a single nucleotide position [6-8]. Molecular studies showed also that zymodemes included distinct DNA genotypes [7,9]. Consequently, other molecular studies do not always agree with the classification of Leishmania by MLEE. The other limitations of MLEE are that it requires 
bulk cultures of parasites, it is time-consuming, and it can be performed only in specialized laboratories. Therefore, alternative DNA based tools and assays are increasingly developed and used for effective investigation and characterization of the parasites.

Indeed, the diversity of Leishmania species, their vectors and their reservoir hosts is a main feature of leishmaniasis, so consequently the transmission cycles are very much dependent on the environment and are very prone to changes. So not only parasite identification is needed to establish etiology of the disease and understand the pathogeny, but knowledge of parasite diversity and its population structure is also needed for a better understanding of ecoepidemiology and its changing trends. For this purpose, molecular tools have been developed to allow differentiation of Leishmania parasites at species and strain levels within environmental or patients' samples.

Molecular tools are based mainly on the amplification and subsequent restriction fragment length polymorphism (PCR-RFLP) of several targets including repeated gene families and coding and non-coding regions, or the sequence analysis of the products. Recently multilocus sequence typing (MLST) and multilocus microsatellite typing (MLMT) were also developed for Leishmania DNA typing. Each of these molecular markers or tools has its specific discriminatory power, advantages and drawbacks.

\section{Parasite identification}

\subsection{Differentiation at the genus level}

This is based on the amplification of the kinetoplast minicircle DNA (kDNA, about 10000 copies per cell) or the variable sequences of the small subunit ribosomal DNA genes (SSU rDNA, 40-200 copies per cell) [10-13].

kDNA and SSU rDNA primers were initially designed for Trypanosomatids including Leishmania, Sauroleishmania, Crithidia and Trypanosomes. They allow identification of Leishmania parasites only at the generic and/ or subgeneric level. Both targets have also been used for the development of real-time PCR assays in order to determine parasite burden in clinical samples [14,15].

\subsection{Differentiation at the species level}

The ability to distinguish between Leishmania species is crucial for a correct diagnosis of the disease as well as for making decisions regarding treatment and control measures. This is especially useful in areas where several Leishmania species co-exist.

Numerous PCR approaches have been published based on different coding and noncoding regions in the Leishmania genome. Different targets have been used, including the ribosomal internal transcribed spacer (ITS) [12,16,17], the mini-exon genes [18,19], gp63 genes [20,21], hsp70 genes [22-24] and cysteine proteinase B gene sequences (cpB) $[25,26]$. 


\subsubsection{Randomly amplified polymorphic DNA (RAPD) and anonymous markers}

Randomly amplified polymorphic DNA (RAPD) technique is based on the PCR amplification of DNA fragments using only one short primer that was arbitrarily defined and thus could be applied to any organism without a prior knowledge on the genome [27]. Such primers correspond to decamers having 60-70 \% GC content and no self-complementary ends, thus the number of primers that could be used is virtually unlimited. Only in few occasions, two primers were used for Leishmania DNA analysis [28]; primers longer than 10 mers like universal primers used in cloning technologies have been used in some instances [29-32]. A list of selected primers used for Leishmania characterization is reported on Table 1. The RAPD technique generates monomorphic or polymorphic banding patterns, analyzed upon electrophoresis on agarose gels (or other supports) like DNA fingerprints. Given the fact that in comparison studies absence of bands does not reflect absence of corresponding DNA fragment in the compared DNA [33,34], the analysis is based only on Jaccard (or equivalent) distance or Similarity index [33] that only takes into account the presence of bands. RAPD reaction is very sensitive to reaction conditions even when variations are minor. Relaxed conditions and particularly low annealing temperature underlie DNA amplification but concentration or batch (quality) of DNA, reaction component, additives, brand of DNA polymerase, thermocyclers impact size range, complexity and reproducibility of the amplification profiles [33,35]. Molecular mechanisms underlying Leishmania DNA amplification was proposed to be based mainly on DNA mutations occurring on potential priming sites, that seem to be in regions enriched for short repeated motives [34].

Potential of RAPD and a selection of 28 primers was assessed for the discrimination between members of the Leishmania Viannia sub-genus which have overlapping geographical distribution in Latin America and that were difficult to distinguish by the conventional PCR using the primers then available. The authors have identified primers able to distinguish the 4 species (L. braziliensis, L. guyanensis, L. panamensis and L. peruviana) in a pair wise way. They also addressed the reliability of the technique by developing a statistical measure of the variation range of Jaccard coefficient when comparing the parasites [33].

\begin{tabular}{|c|c|c|c|c|c|}
\hline Primer & $\begin{array}{c}\text { Nucleotide } \\
\text { sequence 5'-3' }\end{array}$ & References & Primer & $\begin{array}{l}\text { Nucleotide sequence } \\
\qquad 5^{\prime}-3^{\prime}\end{array}$ & References \\
\hline OPA-01 & CAGGCCCTTC & {$[30,34,36,43,44]$} & OPR-16 & CTCTGCGCGT & [38] \\
\hline H4 (OPA-02) & TGCCGAGCTG & {$[31,41,46]$} & OPR-20 & ACGGCAAGGA & [38] \\
\hline C4 (OPA-04) & AATCGGGCTG & [41] & OPU-15 & ACGGGCCAGT & [38] \\
\hline A5, P8, (OPA-05) & AGGGGTCTTG & {$[31,38,41,48]$} & OPU-16 & CTGCGCTGGA & [38] \\
\hline A4, (OPA-07) & GAAACGGGTG & {$[30,31,36,41,43]$} & OPU-02 & CTGAGGTCTC & [43] \\
\hline OPA-08 & GTGACGTAGG & {$[28,30,31,33]$} & ILO 509 & TGGTCAGTGA & [42] \\
\hline OPA-09 & GGGTAACGCC & [31] & ILO 526 & GCCGTCCGA & [42] \\
\hline OPA-10 & GTGATCGCAG & $\begin{array}{c}{[28,30,31,36,38,43,} \\
48]\end{array}$ & ILO 872 & CCCGCCATCT & [42] \\
\hline A12 (OPA-12) & TCGGCGATAG & [41] & ILO875 & GTCCGTGAGC & {$[41,42]$} \\
\hline
\end{tabular}




\begin{tabular}{|c|c|c|c|c|c|}
\hline Primer & $\begin{array}{c}\text { Nucleotide } \\
\text { sequence 5'-3' }\end{array}$ & References & Primer & $\begin{array}{l}\text { Nucleotide sequence } \\
\qquad 5^{\prime}-3^{\prime}\end{array}$ & References \\
\hline A15 (OPA-15) & TTCCGAACCC & [41] & ILO 876 & GGGACGTCTC & {$[42]$} \\
\hline D10 (OPA-20) & GTTGCGATCC & [41] & ILO 878 & GTCGCGGAG & [42] \\
\hline D8 (OPA-16) & AGCCAGCGAA & [41] & $A 5, C 5$ & CTCACGTAGG & {$[39,41]$} \\
\hline OPB-01 & GTTTCGCTCC & [30] & C6 & CTGATCGCAG & [41] \\
\hline C (OPB-04) & GGACTGGAGT & {$[28,33,43,44]$} & L2 & CGGACGTCGC & [41] \\
\hline B5 (OPB-05) & TGCGCCCTTC & [41] & $\mathrm{H} 1$ & CGCGCCCGCT & {$[39,41]$} \\
\hline B6 (OPB-06) & TGCTCTGCCC & [41] & L15996 & $\begin{array}{c}\text { CTCCACCATTAGCACCC } \\
\text { AAAGC }\end{array}$ & {$[29,32]$} \\
\hline OPB-07 & GGTGACGCAG & {$[30,41]$} & $\lambda g 11 R$ & $\begin{array}{l}\text { TTGACACCAGACCAACT } \\
\text { GGTAAT }\end{array}$ & {$[29,32]$} \\
\hline OPB-08 & GTCCACACGG & {$[38,41]$} & M13a, M13 & $\begin{array}{c}\text { GTAAAACGACGGCCAG } \\
T\end{array}$ & {$[30,33]$} \\
\hline OPB-09 & TGGGGGACTC & {$[30,33]$} & $\begin{array}{c}\mathrm{M} 13-40 \mathrm{~F} / \mathrm{M} 13 \\
(-40) \text { a }\end{array}$ & GTTTTCCCAGTCACGAC & {$[29,30,32]$} \\
\hline OPB-10 & CTGCTGGGAC & {$[43,44]$} & M13/pUC & $\begin{array}{c}\text { CGCCAGGGTTTTCCCAG } \\
\text { TCACGA }\end{array}$ & [31] \\
\hline OPB-12 & CCTTGACGCA & {$[30,41]$} & P53-1 & $\begin{array}{c}\text { ACGACAGGGCTGGTTG } \\
\text { CCCA }\end{array}$ & [32] \\
\hline OPB-13 & TTCCCCCGCT & {$[33,41]$} & PLiD2-9 & $\begin{array}{c}\text { CAAAAGTCCCCACCAA } \\
\text { TCCC }\end{array}$ & [42] \\
\hline OPB-15 & GGAGGGTGTT & {$[30,43]$} & QG1 & $\begin{array}{c}\text { CCATTAGCACCCAAAG } \\
\text { CAGACCTCACCCTGTGG } \\
\text { AGC }\end{array}$ & {$[29,32]$} \\
\hline A (OPB-18) & CCACAGCAGT & {$[28,30,33]$} & TA150 & $\begin{array}{c}\text { ATGCGATGAGTGGTTG } \\
\text { AG }\end{array}$ & {$[41,42]$} \\
\hline OPF-01 & ACGGATCCTG & [38] & TA610 & $\begin{array}{c}\text { TCAACCGATTACAAACC } \\
\text { A }\end{array}$ & [42] \\
\hline OPF-10 & GGAAGCTTGG & {$[43,44]$} & UMS & GGGGTTGGTGTA & {$[31,46]$} \\
\hline OPF-13 & GGCTGCAGAA & {$[38,43]$} & 37 & $\begin{array}{c}\text { TGGATCCGGAATTTCGG } \\
\text { CTTCACTAC }\end{array}$ & [42] \\
\hline OPN-13 & AGCGTCACTC & [38] & 198 & GCAGGACTGC & [41] \\
\hline OPN-20 & GGTGCTCCGT & [38] & 233 & CTATGCGCGC & [35] \\
\hline OPR-13 & GGACGACAAG & [38] & 283 & CGGCCACCGT & {$[35,48]$} \\
\hline OPR-14 & CAGGATTCCC & [38] & 3301 & TCGTAGCCAA & {$[30,33]$} \\
\hline OPR-15 & GGACAACGAG & {$[38,43,44]$} & & & \\
\hline
\end{tabular}

Name and sequence of the primers are reported on the table as described in the references. However, for the purpose of this work all the sequences were compared to lists provided by Operon Technologies (OP); primers thus identified are reported within brackets. Primers presenting discrepancies were not reported.

Table 1. Selection of primers used in RAPD analyses of Leishmania parasites generating polymorphic patterns. 
We have used the RAPD technique to identify and discriminate Old World species using 57 strains from different hosts, countries and reservoirs. Six random primers were tested from which 3 allowed to distinguish L. aethiopica, L. arabica, L. donovani, L. major, L. tropica and L. turanica species. We have analyzed the RAPD profiles considering criteria of consistent presence of amplified bands at the same electrophoretic presence for strains/ isolates of the same species, and the discrimination between parasites belonging to different species. This constitutes a simpler way to results interpretation that emphasizes on presence of consistently amplified and discriminative bands within a profile to overcome lack of reliability of RAPD [36]. RAPD also allowed differentiating Old World Leishmania species from the often cosympatric Sauroleishmania parasites [30,36].

Random amplification of polymorphic DNA has been also used alone or with other techniques to confirm taxonomic status of parasites, for instance putative natural hybrids such as $L$. braziliensis/L. panamensis hybrids isolated in Nicaragua [33] or L. braziliensis and L. panamensis/ guyanensis in Ecuador [37]. In another example, genetic analysis of Leishmania parasites in Ecuador with MLEE and RAPD questioned the separation of L. panamensis and L. guyanensis as distinct taxa as these tools failed to generate clearly distinct clusters of parasites [38].

The RAPD technique was also used to investigate genetic diversity within Leishmania species or complexes in diverse settings. Causal agents of visceral leishmaniasis belong to the $L$. donovani complex, which includes the species L. donovani, L. infantum, L. chagasi and $L$. archibaldi [39]; however, taxonomy within this complex is controversial considering for instance L. infantum as forming its own complex [40]. The RAPD technique has been used to investigate intraspecific diversity of the L. donovani complex, using an initial set of 43 random primers [41]. Like in other studies [36,42], some primers differentiated the L. donovani complex from the other Old World taxa. Seven distinguished within the complex, differentiating in the tested panel of DNAs, Mediterranean L. infantum from the other parasites of the complex. Strikingly, none of the primers distinguished L. donovani, L. infantum and L. archibaldi taxa. Geographical clustering was observed with 2 strong Indian and East African L. donovani groups and a third Mediterranean L. infantum group in support to a previous study using RAPD in addition to other DNA tools [39]. Distribution of other L. infantum in the dendrogram also supports the paraphyly of L. infantum [41].

L. infantum zymodeme MON-1 has a worldwide distribution and is responsible mainly for a form of VL. RAPD analysis contributed to describe heterogeneity within this zymodeme and to demonstrate its polyphyletic nature [43]. The RAPD technique also highlighted geographical structures of L. infantum in diverse settings. In [42] they have shown that 17 (out of 18) primers tested on 33 strains isolated from diverse hosts in various Spanish regions generated highly polymorphic RAPD patterns that grouped the parasites into two main clusters that included parasites from central-western region in one side and from eastern Spain in the other. This study in addition illustrated intra-zymodemic diversity and lack of correlation with the MLEE analysis conducted on these strains, the clinical or host origin of the parasites. In another example, $53 \mathrm{~L}$. infantum isolates from VL cases and dogs originating from different endemic regions in Brazil were analyzed with 5 RAPD primers (also used in [43]), MLMT and SSR-PCR. RAPD analysis was shown to be the most appropriate to illustrate genetic diversity of the 
parasites. Interestingly, in spite of the homogenous genetic background the polymorphisms observed demonstrated correlation with geographical origin [44].

In Corte Pedra, North Eastern Brazil, L. braziliensis is causing different American Tegumentary Leishmaniasis (ATL) forms. Forty-five L. braziliensis strains isolated from patients having different ATL forms were shown to generate with 3 primers and 4 protocols, RAPD patterns having overall more than $80 \%$ fingerprint identity classifying the parasites into 5 clades. Significant distribution frequency of the different clinical forms along the clades was observed. The authors thus concluded on the suitability of the RAPD analysis of parasite strains' variability in Corte Pedra and that in such a spatially limited population geographical isolation precludes geographic sequestration as the mechanism for the observed genetic structures. In addition they assumed that infection with some L. braziliensis genotypes could be accompanied with different pathogenic mechanisms [28]. Other studies investigating L. braziliensis diversity in Brazil with other primers also highlighted contrasted diversity extent of parasites isolated from cutaneous leishmaniasis according to the transmission areas; parasites from Mato Grosso [32] or from Para [29] states were more diverse than the ones in Minas Gerais. These authors proposed that eco-epidemiology of the parasites in relation to environmental and geographical differences could explain in part such diversity patterns. Genetic diversity using intergenic region typing (ITSrDNA PCR-RFLP) and MLEE of L. braziliensis from diverse hosts and geographical origins in Brazil also illustrated occurrence of geographical clusters of parasites exerting different levels of variability; association of L. braziliensis to specific transmission cycles likely reflecting adaptation of different parasite clones to the vector (and diversity of) species involved in the transmission has been inferred [45].

The RAPD technique has also been used to investigate epidemiology of leishmaniases, characterizing clinical or field isolates in diverse settings. For instance, in India the increasing reports on drug resistance of the VL patients and the implication of L. tropica as a causal agent of VL, also hypothesized to be a potential reason for drug unresponsiveness [2], has prompted investigations of the causal agents of VL using various DNA tools. A first study for example characterized by MLEE and 8 RAPD primers 15 clinical isolates collected over 20 years from the eastern part of India from confirmed VL patients; this sample study comprised 1 PKDL and 6 antimony unresponsive cases. All parasites proved to be L. donovani [31]. Another study investigated with the same primers 9 other parasites isolated over the period 2006-2010 from hospital clinics in Kolkata from confirmed VL and a PKDL cases; one parasite was similar to L. tropica while the others were very close to L. donovani [46]. The association of L. tropica with the disease was further confirmed in another study using ITS, ITS1 and HP70 based assays [47]. In Iran, where cutaneous leishmaniasis is highly endemic, MLEE and kDNA were used to identify species of 565 parasites obtained from confirmed CL patients from the different provinces of the country during the 2002-2008 period [48]; this study associated L. major mainly to rural transmission and L. tropica to urban settings. RAPD using 3 primers allowed describing extensive genetic heterogeneity of a random selection of 65 L. major strains across the different transmission area and within the same foci.

In addition, RAPD technique constitutes a powerful alternative to the identification of PCR targets and markers. RAPD markers have been exploited for the design of species or complex 
specific PCR assays like for instance a PCR that only amplifies DNA of parasites of the $L$. donovani complex [34] or another that amplifies exclusively L. braziliensis [49]. Such markers proved to be highly informative as probes or as PCR targets [34].

Randomly amplified polymorphic DNA products were used to develop markers that were targeted to develop typing strategies. For example, RAPD products that were amplified consistently across tested DNAs with a combination of 2 primers have been selected and sequenced partially to design marker specific PCR primers. The resulting PCR products were then screened for single stranded conformation polymorphisms (SSCP) and subsequently confirmed by sequence analysis [50]. This sequence confirmed amplified region analysis (SCAR) approach was used to differentiate 29 L. donovani strains from Sudan, Kenya, India and China using 8 different markers. The study identified 19 unique multilocus genotypes and a correlation between genotypes and geographical origin; SCAR markers were considered as co-dominant for their ability to detect all possible allele combinations in a diploid organism and as a representative random sample of neutral genetic variation in natural populations thus constituting appropriate tools for population studies [50].

Alternatively, with the objective to identify markers and develop simple assays for the discrimination of viscerotropic parasites encountered in Africa, we have screened 5 Operon kits (100 primers) for reproducible profiles and a selection of 28 primers was then used to screen for DNA markers within a panel of viscerotropic parasites from different countries in Africa and India [51]. These primers organized the parasites according to their geographical origin in a similar way to other studies using RAPD or other types of tools [39,41]. Some of the differentially amplified RAPD bands obtained in our study were cloned and sequenced; their analysis with bioinformatics tools and comparison to their respective genomic sites in $L$. infantum, L. donovani and L. major genomes highlighted the markers' association with simple sequence repeats and microsatellites in non coding regions [51]. A selection of such markers in $L$. archibaldi was used to develop simple PCR assays differentiating viscerotropic parasites, some of which in a country-specific way [52].

Randomly amplified polymorphic DNA is highly suitable for analysis of cultured Leishmania promastigotes but of limited interest for analysis of patients or zoonotic samples due to sample contamination with host DNA. Its use could be however contemplated to characterize promastigotes at the isolation step given the technique does not require large amounts of DNA (20 ng or less). Another generally admitted drawback is the lack of reproducibility generated by complex reactions occurring under the relaxed reaction conditions, therefore interlaboratory or inter-study comparison using the same primers appear difficult to achieve. Options to overcome this drawback were the prior selection of primers of interest, or the use of defined criteria for analysis as for example relying only on consistently observed bands within RAPD patterns to assign the parasites to taxonomic groups [36] or using statistical tools to assess significance of the range of distances evaluated [33]. Use of well-standardized protocols may also help overcoming such a drawback. Although simple and having potential for detecting variation where other techniques fail, other drawbacks of this technique could be that bands of equal electrophoretic mobility may not be homologous [34]; identification of allelic variants is also not possible in Leishmania. Yet, RAPD constitutes a powerful tool for the 
identification of markers and the design of PCR based assays [34, 49-52]. Diverse RAPD Leishmania studies reached conclusions that were confirmed by other tools or alternative studies making the RAPD approach still valuable.

\subsubsection{Gp63 PCR-RFLP and sequencing analyses}

Gp63 genes encode for the major metalloprotease of Leishmania, which is the most abundant surface glycoprotein found in promastigote and amastigote forms of the parasite. GP63 protein is encoded by a cluster of tandemly repeated genes, and has been identified as a virulence factor in several Leishmania species. Several groups have studied the potential of gp63 as a species discriminatory tool in Leishmania. Amplification of gp63 genes coupled with restriction analysis (PCR-RFLP) was applied to a large number of isolates belonging to 4 species of the subgenus Viannia, namely L. (V.) braziliensis, L. (V.) peruviana, L. (V.) guyanensis and L. (V.) lainsoni and allowed discrimination of all the species tested [20] (Table2).

\begin{tabular}{|c|c|c|c|c|c|}
\hline \multirow{3}{*}{ Target } & \multirow{3}{*}{ Primers sequences $\left(5^{\prime}-3^{\prime}\right)$} & \multirow{3}{*}{ Product size (bp) } & \multicolumn{2}{|c|}{ Discrimination } & \multirow{3}{*}{ Refs } \\
\hline & & & by & & \\
\hline & & & PCR-RFLP & Seq. & \\
\hline \multirow{8}{*}{ kDNA } & (F) Pia1: ACGAGGTCAGCTCCACTCC & \multirow[t]{2}{*}{100} & - & - & \multirow[t]{8}{*}[11,13]{} \\
\hline & (R) Pia2: CTGCAACGCCTGTGTCTACG & & - & - & \\
\hline & (F) Pia3: CGGCTTCGCACCATGCGGTG & \multirow[t]{2}{*}{260} & - & - & \\
\hline & (R) Pia4: ACATCCCTGCCCACATACGC & & - & - & \\
\hline & (F) K13A : GTGGGGGAGGGGCGTTCT & \multirow[t]{2}{*}{120} & & & \\
\hline & (R) K13B: ATTTTACACCAACCCCCAGTT & & & & \\
\hline & (F) RV1: CTTTTCTGGTCCCGCGGGTAGG & \multirow[t]{2}{*}{145} & & & \\
\hline & (R) RV2: CCACCTGGCCTATTTTACACCA & & & & \\
\hline \multirow{2}{*}{ SSU rDNA } & (F) R221: GGTTCCTTTCCTGATTTACG & \multirow{2}{*}{603} & \multirow{2}{*}{+} & \multirow{2}{*}{+} & \multirow{2}{*}{ [10] } \\
\hline & (R) R332: GGCCGGTAAAGGCCGAATAG & & & & \\
\hline \multirow{8}{*}{ Gp63 } & (F) TDM1: GTCTCCACCGCAGACCTCACGGA & \multirow{2}{*}{1300} & \multirow{2}{*}{+} & \multirow{2}{*}{ - } & \multirow{2}{*}{ [20] } \\
\hline & (R) TDM2: TGATGTAGCTGCCATTCACGAAG & & & & \\
\hline & (F) SG1: GTCTCCACCGAGGACCTCACCGA & \multirow[t]{2}{*}{1300} & \multirow[t]{2}{*}{+} & \multirow[t]{2}{*}{-} & \multirow{4}{*}[21]{} \\
\hline & (R) SG2: TGATGTAGCCGCCCTCCTCGAAG & & & & \\
\hline & (F) PDD1: TCGGTGAGGTCCTCGGTGGAGAC & \multirow[t]{2}{*}{1700} & \multirow[t]{2}{*}{+} & \multirow[t]{2}{*}{-} & \\
\hline & (R) PDD2: CTTCGAGGAGGGCGGCTACATCA & & & & \\
\hline & (F) C9F: GGCTCCCGACGTGAGTTA & \multirow[t]{2}{*}{1750} & \multirow[t]{2}{*}{+} & \multirow[t]{2}{*}{ - } & \multirow{2}{*}{ [58] } \\
\hline & (R) C1R: GGGCCCGGGCGACAGCAGCGATGACTG & & & & \\
\hline
\end{tabular}


(F) C10F: GGGAAGCTTACGTACAGCGTGCAGGTG

1600,2000 and 4500

(R) C1R: GGGCCCGGGCGACAGCAGCGATGACTG

\begin{tabular}{|c|c|c|c|c|c|}
\hline \multirow{2}{*}{ ITS } & (F) LITSV: ACACTCAGGTCTGTAAAC & 1040 or & + & + & \multirow{2}{*}[64,65,69]{} \\
\hline & (R) LITSR: CTGGATCATTTTCCGATG & $950-1100$ & + & + & \\
\hline \multirow{4}{*}{ ITS1 } & (F) IR1: GCTGTAGGTGAACCTGCAGCAGCTGGATCATT & \multirow{2}{*}{$1000-1200$} & \multirow{2}{*}{+} & \multirow{2}{*}{-} & \multirow{2}{*}[16]{} \\
\hline & (R) IR2: GCGGGTAGTCCI'GCCAAACACTCAGGTCTG & & & & \\
\hline & (F) LITSR: CTGGATCATTTTCCGATG & \multirow{2}{*}{$300-350$} & \multirow{2}{*}{+} & \multirow{2}{*}{+} & {$[12,13,61,6$} \\
\hline & (R) L5.8S: TGATACCACTTATCGCACTT & & & & $5,82]$ \\
\hline \multirow{4}{*}{ ITS2 } & (F) LGITSF2: GCATGCCATATTCTCAGTGTC & \multirow{2}{*}{$372-450$} & \multirow{2}{*}{-} & \multirow{2}{*}{+} & \multirow{2}{*}{ [63] } \\
\hline & (R) LGITSR2: GGCCAACGCGAAGTTGAATTC & & & & \\
\hline & (F) L5.8SR: AAGTGCG-ATAAGTGGTA & \multirow{2}{*}{720} & \multirow{2}{*}{-} & \multirow{2}{*}{+} & \multirow{2}{*}{ [65] } \\
\hline & (R) LITSV: ACACTCAGGTCTGTAAAC & & & & \\
\hline \multirow{2}{*}{$\begin{array}{l}\text { ITS1and part } \\
\text { of ITS2 }\end{array}$} & (F) LITS-MG: ATG GCC AAC GCG AAG TTG & \multirow{2}{*}{800} & \multirow{2}{*}{-} & \multirow{2}{*}{+} & \multirow{2}{*}[69]{} \\
\hline & (R) LITSR: CTGGATCATTTTCCGATG & & & & \\
\hline & PCR-G : (F) HSP70sen: GACGGTGCCTGCCTACTTCAA & \multirow{2}{*}{1422} & \multirow{2}{*}{+} & \multirow{2}{*}{-} & \multirow{2}{*}[22,72]{} \\
\hline & (R) HSP70ant: CCGCCCATGCTCTGGTACATC & & & & \\
\hline & PCR-F : (F) F25: GGACGCCGGCACGATTKCT & \multirow{2}{*}{1286} & + & & \\
\hline & (R) R1310: CCTGGTTGTTGTTCAGCCACTC & & + & - & \\
\hline & PCR-N : (F) F25: GGACGCCGGCACGATTKCT & 593 & + & & {$[73-75]$} \\
\hline & (R) R617: CGAAGAAGTCCGATACGAGGGA & כנכ & $T$ & & ] \\
\hline & PCR-C : (F) F251: GACAACCGCCTCGTCACGTTC & 741 & 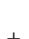 & & \\
\hline & (R) R991: GTCGAACGTCACCTCGATCTGC & 141 & $T$ & & \\
\hline & (F) HSP70sen: GACGGTGCCTGCCTACTTCAA & ברכ11 & & 1 & \\
\hline & (R) HSP70ant: CCGCCCATGCTCTGGTACATC & $14 \angle 2$ & - & + & \\
\hline $\mathrm{Hen} 70$ & (F) HSP70-F335 CACGCTGTCGTCCGCGACG & 113 & - & + & \\
\hline nspio & (R) HSP70-R429 AACAGGTCGCCGCACAGCTCC & נודו & & r & (2) \\
\hline & (F) HSP70-2F CTGAACAAGAGCATCAACCC & 170 & & + & \\
\hline & (R) HSP70-2R CTTGATCAGCGCCGTCATCAC & 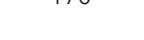 & & $T$ & \\
\hline & (F) HSP70-F893 GTTCGACCTGTCCGGCATCC & 130 & & & \\
\hline & (R) HSP70-R1005 GTGATCTGGTTGCGCTTGCC & & - & + & \\
\hline & PCR-F : (F) HSP70-F25: GGACGCCGGCACGATTKCT & 1286 & - & + & \\
\hline & (R) HSP70-R1310: CCTGGTTGTTGTTCAGCCACTC & 1200 & 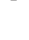 & + & \\
\hline & PCR-T : (F) HSP70-6F GTGCACGACGTGGTGCTGGTG & 766 & & + & [76] \\
\hline & (R) HSP70-R1310: CCTGGTTGTTGTTCAGCCACTC & & & r & \\
\hline & PCR-N : (F) HSP70-F25: GGACGCCGGCACGATTKCT & 503 & & $2+$ & \\
\hline & (R) HSP70-R617 CGAAGAAGTCCGATACGAGGGA & הכלו & & $T$ & \\
\hline
\end{tabular}


3'UTR : (F) 70-IR-D: CCAAGGTCGAGGAGGTCGACTA

(R) 70-IR-M: ACGGGTAGGGGGAGGAAAGA

$516-733$

[77]

(F) Fme: TATTGGTATGCGAAACTTCCG

(R) Rme: GAAACTGATACTTATATAGCG

$220-443$

$+\quad+[19,13,78]$

Mini-exon

(F) FME2: ACTTCCGGAACCTGTCTTCC (Leishmania

subgenus) or ACTTCCGGGACCCGTCTTCC (Viannia

$$
\text { subgenus) }
$$

$220-443$

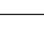

(R) ME2R: CAGAAACTGATACTTATATAGCGTTA

\begin{tabular}{|c|c|c|c|c|c|}
\hline \multirow{4}{*}{$\begin{array}{l}\text { Cysteine } \\
\text { protease B }\end{array}$} & $\begin{array}{l}\text { intragenic region: } \\
\text { (F) CPBFOR: CGAACTTCGAGCGCAACCT } \\
\text { (R) CPBREV: CAGCCCAGGACCAAAGCAA }\end{array}$ & 1079 & + & - & \multirow{2}{*}[83,84]{} \\
\hline & $\begin{array}{l}\text { Intergenic region : } \\
\text { (F) PIGS1A: CCTCATTGCTTTGGTCCTGG } \\
\text { (R) PIGS2B: GGCGTGCCCACGTATATCGC }\end{array}$ & 1600 & + & - & \\
\hline & $\begin{array}{c}\text { cpbEF: } \\
\text { (F) CGTGACGCCGGTGAAGAAT } \\
\text { (R) CGTGCACTCGGCCGTCTT }\end{array}$ & $702-741$ & - & - & {$[25,85]$} \\
\hline & $\begin{array}{c}\text { cPbEF: } \\
\text { (F) CGTGACGCCGGTGAAGAAT } \\
\text { (R) CGTGCACTCGGCCGTCTT }\end{array}$ & $702-741$ & + & + & [26] \\
\hline
\end{tabular}

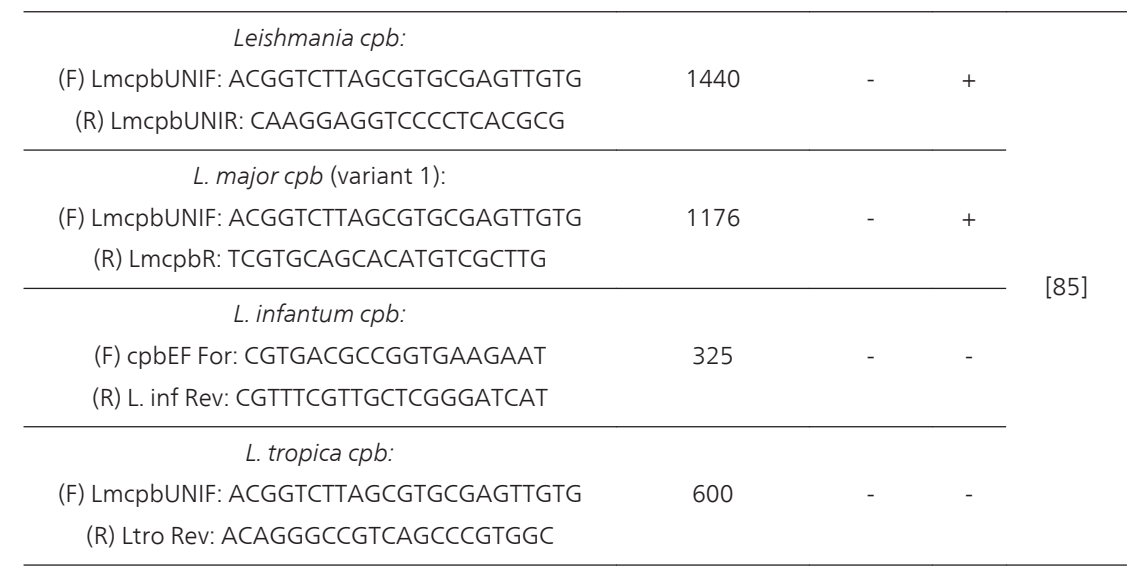

L. infantum cpb:

(F) infcpbE: GTCTTACCAGAGCGGAGTGCTACT

278

(R) Inf2.1: ATAACCAGCCATTCGGTTTTG

L. donovani cpb:

[86]

(F) cpbF2.1: GCGGCGTGATGACCAGC

309

(R) Do2.1: CAATAACCAGCCATTCGTTTTTTA

(F) MATRAE2: GGCGATGGTGGAGCAGATGATCT 
(R) Ma4.1: CGGTTCTCGTAGCACACTTGTTG

(R) Tr4.1: CTCCCCCGTTCGGAT

(R) Ae2.1: AGTACGTGCACATCAGCACATGGG
99 (L. major)

100 (L. tropica)

$154(L$.

aethiopica)

(F) V5F: GGTGATGTGCCCGAGTGCA

(R) V10R: CGTGCACATCAGCACATGGG

564

(F) CpbF: GTGCGTGCGGGTCGTGC

(R) CpbR: AAAGCCCCGGACCAAAGCA

(F): Forward primer; (R): Reverse primer; Seq.: sequence analysis; Refs: references

Table 2. Overview of DNA targets, primers sequences, product sizes and the technique used to achieve discrimination of Leishmania taxa.

Gp63 PCR-RFLP tool was also used to characterize isolates representative of the L. donovani complex (L. infantum, L. donovani, L. archibaldi and L. chagasi), with special attention to Mediterranean L. infantum from different geographical origins, in addition to representative strains of Old World Leishmania (L. major, L. tropica and L. aethiopica) [21] (Table2). This allowed discrimination of the 4 species of the $L$. donovani complex, which were quite distinct from the outgroup. Within L. infantum, the parasites were found to be polymorphic showing a geographical structuring [21]. Sequences of the gp63 genes were explored in 33 strains of the $L$. donovani complex having different origins and zymodemes, in addition to reference strains of other Old World species [53]. Evolution of the gp63 multigene family was inferred to be under the influence of a mosaic or fragmental gene conversion mechanism. The sequences clustered according to the species, showing a concerted evolution of the different gene classes. Phylogenetic analyses confirmed the genetic diversity of the L. donovani complex, which showed that gp63 genes could provide the basis for rapid and reliable genotyping of strains in this complex [53].

Furthermore, still using gp63 coding sequences PCR-RFLP evaluated intra-specific polymorphism of L. infantum isolates in Tunisia [54]. In total, 22 L. infantum isolates responsible of visceral (14 isolates) and cutaneous (8 isolates) forms of leishmaniasis in Tunisia were analysed, in addition to reference isolates, representative of Old World complexes. The SalI, HincII, BalI and BsiEI restriction enzymes were used in this intragenic gp63 PCR-RFLP analysis. Results showed profiles that allowed distinction of L. infantum from the other species belonging to the L. donovani complex (L. donovani, L. archibaldi and L. chagasi) but also from the Old World species L. major, L. tropica and L. aethiopica. Besides, polymorphic patterns were observed among $L$. infantum isolates that tend to be correlated to the clinical presentation of the disease; the phenetic analysis using a UPGMA clustering method (Phylip package) grouped all VL isolates together while most of the CL parasites clustered in a separate branch. Good bootstrapping values supported the clusters [54].

The gp63 PCR-RFLP method was applied to characterise parasites contained within the lesions of patients having cutaneous leishmaniasis, originating from areas in central Tunisia, known 
to be free of CL. This analysis confirmed assignment of the parasites to the L. infantum species, thus demonstrating the occurrence/emergence of sporadic cutaneous leishmaniasis (SCL) due to L. infantum in central Tunisia [55].

The gp63 PCR associated to RFLP analysis was also used to characterise transmitted Leishmania in Sudan. Patients that presented with uncommon cutaneous leishmaniasis, including one case with a L. tropica like-lesion, were confirmed, using this tool, to be infected by L. major [56]. In another study, Leishmania parasites from Sudanese patients having cutaneous ulcers were analyzed by gp63 PCR-RFLP and shown to belong to the L. donovani species [56]. This work allowed concluding that, in addition to L. major, L. donovani species can also be a major cause of CL in Sudan [57].

Another PCR-RFLP analysis of the gp63 intergenic region was also developed and tested on the L. donovani complex [58]. The markers generated robust and congruent phylogenies, identifying 5 genetic clusters within L. donovani complex. Furthermore, clusters strongly correlated with isoenzyme typing and some with geographical origin, which may be important for epidemiological and clinical studies [58].

Although the gp63 PCR RFLP technique has been successfully used for Leishmania discrimination at the species and strains levels, it presents several disadvantages. The fragment patterns obtained are sometimes vey complex and can be difficult to analyze and compare between laboratories. Also, partial restriction needs to be carefully evaluated as a potential source of artefacts. This technique depends therefore, on careful standardization and is recommended for comparative studies involving few strains rather than for large-scale epidemiological studies. Given the size of the sequences amplified (1.3Kb for the intragenic PCR) and the number of (GC rich) copies, the PCR assay requires good quality DNA and additives like DMSO [21] and thus a careful establishment step.

\subsubsection{ITS1 PCR-RFLP and ITS2 targets}

Ribosomal RNA (rRNA) genes are highly repetitive and conserved sequences. The ITS1 region is the sequence in between the $18 \mathrm{~S}$ rRNA and $5.8 \mathrm{~S}$ rRNA genes. It has enough conservation to serve as a PCR target but sufficient polymorphisms to facilitate species typing. ITS1 PCR has been developed in combination with an RFLP analysis (Table2) with different restriction enzymes (AluI, BstUI, EcoRI, FspI, HaeIII, HhaI, RsaI, Sau3AI, SphI and TaqI) [16]; HaeIII is the mostly used restriction enzyme used for species identification. Indeed, ITS1 PCR-RFLP using HaeIII is the most widely used assay for direct detection and identification of Leishmania species in the Old World.

It has been applied for the distinction of sympatric species, especially in the Mediterranean region $[59,60]$. However, representatives of the L. donovani complex (L. donovani and L. infantum) and also of the L. braziliensis complex (L. braziliensis, L. guyanensis, L. panamensis, L. peruviana) cannot be distinguished by this approach, even using a great variety of restriction enzymes [12]. This limitation can however be bypassed by sequencing of the ITS1 PCR product thus allowing for a clear separation of these species and also assignment of different strains [61]. 
Recently, real-time PCR product from the ITS1 region has been used in a high-resolution melt (HRM) analysis in order to identify and quantify Old World Leishmania species [62]. High resolution melt analysis is a molecular technique that uses a fluorescent intercalating dye to measure the rate of double stranded DNA dissociation consequent to an increase of temperature. The observed melting curve is characteristic of a particular DNA and depends on its sequence length, GC content, complementarity, and nearest neighbour thermodynamics. The dye is incorporated during the amplification; the DNA dissociation measures occur at the end of the PCR, which is performed in a dedicated thermocycler. The results are computerized and analyzed through a graphic output. When tested on 300 samples from human cases, reservoir hosts and sand flies, this approach distinguished all Old World Leishmania species causing human disease, except L. donovani from L. infantum [62].

The ITS2 region is located in between the 5.8S rRNA and LSU rRNA genes. It has been studied and found to be adequate for species identification. Indeed, generic PCR primers (LGITSF2/ LGITSR2) were designed to amplify this fragment from Leishmania spp. associated with human infection, using reference isolates [63] (Table 2). Substantial differences in the ITS2 region amplified by these primers followed by sequencing analysis, allowed detection of and discrimination among Leishmania species from the Old and New World [63]. The ITS2 PCR followed by DNA sequence analysis approach was validated on clinical specimens, which allowed identification of a total of 8 Leishmania species (L. $(V$.$) braziliensis, L. (V.) guyanensis, L.$ (V.) panamensis, L. (L.) mexicana, L. aethiopica, L. major, L. tropica and the L. donovani complex) among 159 patients corresponding to U.S. civilians that had travel and immigration history to leishmaniasis endemic countries [63].

The ITS1 and ITS2 region have also been used to assess intra-specific DNA polymorphisms among L. donovani isolates from different geographical origins [64,65] (Table 2). Singlestranded conformation polymorphism (SSCP), and sequencing of the ITS regions were applied to clinical samples of L. donovani from Sudan and one from Kenya, one from India and one from China. Intra-specific variation in SSCP banding patterns was clearly observed in the ITS1 region and gave five different SSCP profiles; 3 profiles were detected among Sudan isolates and 2 ITS1-SSCP profiles were observed among the samples from Kenya, India, and China [65]. This corroborates the results of a previous study in which 11 polymorphic ITS1-SSCP patterns were identified among 63 clinical samples of L. donovani from eastern Sudan [64]. On the other hand, no variation was observed in the ITS2 region among the 63 studied cases from Sudan [64] and the study that analyzed the ITS2 locus among 23 Sudanese samples, showed again the same ITS2 SSCP pattern, with the exception of 1 isolate that had a different one [65].

When the species L. tropica was studied using ITS1 amplification and SSCP analysis, 14 SSCP profiles within 29 strains from different Old World geographical areas were found [66,67]. The L. major species was also investigated for DNA polymorphisms using ITS1 and ITS2 PCR amplification followed by SSCP analysis and sequencing [68]. Results revealed in total five genotypic variants among L. major isolates from Iran [68].

Recently, authors from Iran used primers LITSR and LITSV to amplify whole ITS region and found a double banded electrophoretic pattern in L. tropica species, while a sharp single band was observed for L. infantum and L. major isolates [69]. In order to explain how this two-band 
pattern occur in L. tropica, an in silico analysis of ITS sequences was conducted and showed the existence of two groups of sequences that differ by a 100bp gap, indicating existence of at least two alleles for ITS in ribosomal DNA. Thus, a specific reverse primer was developed (LITSMG, Table 2) in order to amplify, with LITSR, sequences located just before the gap, which included ITS1 $5.8 \mathrm{~S}$ and a part of the ITS2 sequence. Amplification using LITS-MG/ LITSR primer set, followed by sequencing, allowed discriminating L. tropica from L. infantum or $L$. major [69].

Although PCR-RFLP of the ITS1 spacer is the most widely used assay for direct detection and identification of Leishmania species in the Old World, it has some limitations. Despite that all medically relevant Leishmania species can be distinguished by digesting the ITS1 PCR product with HaeIII restriction enzyme, representatives of the $L$. donovani complex (L. donovani and $L$. infantum) or L. braziliensis complex (L. braziliensis, L. guyanensis, L. panamensis and L. peruviana) have almost identical RFLP patterns with a great variety of restriction enzymes and cannot be resolved further by this approach [12]. This problem can, however be solved partially by sequencing the ITS1 PCR product. Use of a highly resolutive agarose or SSCP analysis may be needed to resolve differences between some species or to investigate intra-specific polymorphism, respectively. ITS2 region has also served for species identification but the drawback of this approach is the need for DNA sequencing analysis. Sequencing or SSCP analysis may not be available in most laboratories in areas of endemicity.

\subsection{4. hsp70 PCR-RFLP and sequencing}

The 70kDa heat-shock proteins (HSP70) are encoded by genes that are highly conserved across prokaryotes and eukaryotes both in sequence and function. They have great importance as molecular chaperones in protein folding and transport [70]. Genes encoding cytoplasmic HSP70s were among the first kinetoplastid genes that were cloned and characterized because of their conserved nature [71]. HSP70 protein and its encoding gene have been widely used for phylogenetic and taxonomic studies of different parasites, including Leishmania.

The PCR-RFLP approach targeting hsp70 sequences has proven to be most useful for the differentiation between South American Leishmania species from the subgenus Viannia (Table2). Using the restriction enzyme HaeIII to digest the amplified product, the produced RFLP patterns allowed discrimination between $L$. guyanensis species complex as well as for $L$. lainsoni and L. shawi $[22,24]$. However, L. braziliensis and L. peruviana, both belonging to the $L$. braziliensis complex, as well as L. naiffi showed an identical HaeIII RFLP pattern. They can be distinguished by using other restriction endonucleases like MboI and Bst UI [24]. The Hsp70 PCR-RFLP approach was extended for identification of Old World and additional New World species with an improved resolution within species complexes; in total 139 strains from 14 species were studied using HaeIII, BccI, RsaI, MluI, and BsaHI restriction enzymes [72]. Two subsequent digestions of the PCR products identified the species L. infantum and L. donovani (HaeIII and MluI), L. tropica and L. aethiopica (HaeIII and BsaHI), L. braziliensis and L. peruviana (HaeIII and RsaI), L. guyanensis and L. panamensis (HaeIII and BccI); the first digestion using HaeIII discriminates among the broad groups while the additional ones discriminate within these groups; the species L. major, L. lainsoni and L. naiffi had specific patterns with HaeIII 
restriction enzyme, without need to use an additional digestion [72]. However, it was not possible to differentiate between the species L. mexicana, L. amazonensis, and L. garnhami [72].

In order to improve the sensitivity and specificity of the previously reported hsp70 PCR, alternative PCR primers and RFLPs were used [73] (Table2). Thus, three new PCR primer sets (PCR-F, PCR-N, and PCR-C) and their corresponding restriction scheme (RFLP-F, RFLP-N, and RFLP-C) were tested. The detection limit of the new PCRs was between 0.05 and 0.5 parasite genomes; they amplified clinical samples more efficiently, and were Leishmania specific. A specific discriminative power was found for each new RFLP analysis: in general species from the Old World (L. major, L. tropica, L. aethiopica, L. donovani, L. infantum) and from the New World (L. infantum, L. lainsoni, L. peruviana, L. guyanensis, L. panamensis) were well differentiated [73]. Discrimination of L. guyanensis and L. panamensis species, both belonging to the L. guyanensis complex is important for epidemiological purposes and has also consequences for the prognosis of the disease, since MCL, which is principally associated with $L$. braziliensis, can also be caused by other L. (Viannia) suspected species. Recently, an updated hsp70PCR RFLP protocol for RFLP-F and RFLP-N designed in [73] was published, with new restriction enzymes [74]. These new enzymes showed reduced cost and allowed better separation of some New World (sub)species [74].

Relevance of the hsp70 PCR-RFLP approach [72-74] is illustrated by a study that applied it on 89 clinical samples from a total of 73 Peruvian patients with either cutaneous or mucocutaneous leishmaniasis. The new PCRs were tested on tissue samples, lesion biopsies, aspirates, and scrapings. They showed an improved sensitivity both for genus detection and species typing and identified the species L. braziliensis, L. peruviana and L. guyanensis [75].

In addition to PCR-RFLP analysis, the hsp70 gene was also used in sequencing. Indeed, the $1380 \mathrm{bp}$ fragment of the coding region commonly used in RFLP analysis was sequenced in 43 isolates from different geographic origins for studying evolutionary relationships [23]. Fiftytwo hsp70 sequences representing 17 species commonly causing leishmaniasis both in the New and Old World were analyzed. The authors found that the genus Leishmania formed a monophyletic group with three distinct subgenera L. (Leishmania), L. (Viannia), and L. (Sauroleishmania). The obtained phylogeny supported the eight species L. (L.) donovani, L. (L.) major, $L$. (L.) tropica, L. (L.) mexicana, L. (V.) lainsoni, L. (V.) naiffi, L. (V.) guyanensis and L. (V.) braziliensis. In some of the species, subspecies L. (L.) donovani infantum, L. (V.) guyanensis panamensis, and L. (V.) braziliensis peruviana were recognized [23]. Recently, sequencing of the hsp70 gene was useful for Leishmania species determination within clinical samples, overcoming need for parasite isolation [76]. The results obtained were in great agreement with those from multilocus enzyme electrophoresis [76].

The 3'-untranslated region (UTR) of hsp70-type I gene constitutes an alternative target for sequence analysis [77]. These authors who used it to analyse 24 strains representing 11 Leishmania species, found a remarkable degree of sequence conservation in this region, even between species of the subgenera Leishmania and Viannia. In addition, the presence of many microsatellites was a common feature of the 3'-UTR of HSP70-I genes in the Leishmania genus. Global sequence alignments and resulting dendrograms demonstrated usefulness of this particular region of hsp70 genes for species (or species complex) typing, improving the 
discrimination capacity of phylogenetic trees based on hsp70 coding sequences in case of some species (L. donovani/L. infantum; L. tropica and L. aethiopica; L. braziliensis/L. peruviana; L. guyanensis/L. panamensis) [77].

Using hsp70 gene in PCR followed by RFLP or sequence analysis presents many advantages. It is easily comparable across all Leishmania species worldwide and discriminates all relevant species in both subgenera L. (Leishmania) and L. (Viannia). In addition, the approach has been optimized for direct amplification from clinical samples. However, systematic sequencing of the hsp70 gene for Leishmania identification purposes represents the major disadvantage of this approach, since this technique needs high-resource settings. For this, it was stated, "this method is especially suited for use in non-endemic infectious disease clinics dealing with relatively few cases on an annual basis, for which no fast high throughput diagnostic tests are needed" [76].

\subsubsection{Mini-exon PCR-RFLP}

The mini-exon genes are involved in the trans-splicing process of nuclear mRNA in kinetoplastid protozoa and are present as 100 to 200 tandemly repeated copies per nuclear genome. Mini-exon genes contain a highly conserved exon of $39 \mathrm{bp}$ with a moderately variable transcribed intron region (55 to $101 \mathrm{bp}$ ) and a highly variable non-transcribed spacer sequence (51 to $341 \mathrm{bp}$ ). These genes were extensively used as a PCR target to identify and discriminate Old and New World Leishmania species $[19,78]$. This PCR assay amplified all the miniexon sequences in a single reaction (Table2). In addition, size variability of the amplification products allowed preliminary discrimination between the major complexes (Old and New World Leishmania, and New World Viannia complexes). After enzymatic restriction of the PCR product with HaeIII or EaeI, a characteristic RFLP pattern is produced that depends on size variations in the polymorphic spacer regions as well as mutations in the recognition sites of the restriction enzymes. EaeI profiles were shown to be more informative than HaeIII and allowed to distinguish between the most important Old World species, L. major, L. tropica, L. aethiopica, L. infantum and L. donovani $[19,78]$. However, with HaeIII, species belonging to the L. braziliensis complex (L. braziliensis and L. peruviana) and to the L. guyanensis complex (L. guyanensis and L. panamensis) could be discriminated [19].

This genotyping method was successfully applied to naturally infected clinical samples for the differentiation of New and Old World Leishmania species and showed a high sensitivity and a robust and reliable species differentiation power [79]. Several other research groups have applied mini-exon PCR-RFLP method for identification and characterisation of Leishmania species, using various types of samples from different countries. In [80], they have analyzed microcapillary cultivated isolates from cutaneous and visceral cases in Turkey and identified the species L. infantum and L. tropica in CL cases, and L. infantum in VL ones. In Nepal, bone marrow aspirates from VL patients were analyzed by mini-exon PCR-RFLP and the parasites have been shown similar to the standard Indian strain of L. donovani and different from the Kenyan strain [81]. 
Recently, mini-exon PCR-RFLP was compared to the ITS1 PCR RFLP approach on a set of reference strains [82]. The ITS1 PCR proved to be slightly more sensitive and more practical than the mini-exon. Analysis using the ITS1 digested with HaeIII allowed to distinguish most species but an additional digestion with $C f o$ I may be helpful in case of L. mexicana. However, using the mini-exon, sequencing was found to be the most practical approach as the mini-exon sequences add information since they are more polymorphic than the ITS1 sequences [82]. Therefore, the mini-exon genes were used for typing the species that belong to the L. Viannia subgenus, also known as L. braziliensis complex, which cannot be distinguished with the ITS1 [82].

\subsubsection{Cysteine protease B (cpb) based PCR and PCR RFLP}

$\mathrm{Cpb}$ genes are multicopy genes that encode for cathepsin L-like cysteine proteinase B (cpb), a major antigen of Leishmania parasites.

PCR RFLP assays targeting cpb genes and their non-coding inter-genic sequences were also developed and applied for characterization of strains from the L. donovani complex [83] (Table2). The following enzymes were used for intra-genic cpb PCR-RFLP: Hinfl, TaaI, HaeIII, CfrI, HpaII, and SduI, and for inter-genic cpb PCR-RFLP: Eam1104I, NspI, HaeIII, AcyI, and HaeII [83]. The discriminatory power of this assay was compared with that of PCR-RFLP analysis of the gp63 gene, and multilocus enzyme electrophoresis (MLEE). Restriction patterns of the cpb locus were polymorphic, but less so than gp63 patterns and presented differences with MLEE, supporting a different classification of parasites. The applicability of the developed cpb PCR RFLP approach also allowed direct genotyping of parasites in bone marrow aspirates and blood samples obtained from VL patients in Nepal [83]. This cpb PCR RFLP approach, in addition to a gp63 PCR-RFLP analysis, were applied to study 59 isolates of the L. infantum species obtained from different regions in Algeria, originating from various clinical forms and hosts, and assigned to different zymodemes [84]. Among the four analyzed zymodemes, 15 different genotypes were obtained. Also, cpb polymorphism showed two interesting trends: a possible relationship with the cutaneous origin of the isolates and an association with a West-East cline [84].

Different species-specific PCR assays were developed using these genes as target. PCR assays discriminating $L$. donovani from $L$. infantum were developed $[25,26]$. An $L$. donovani speciesspecific PCR primer pair amplifies a 317bp at the 3' end of cpb gene of L. donovani whereas it does not generate an amplicon for L. infantum [26]. Another PCR that was developed based on cysteine protease B genes differentiates $L$. infantum from $L$. donovani by their fragment length: a $741 \mathrm{bp}$ product $(\mathrm{cpbF})$ characterized $L$. donovani strains, and a $702 \mathrm{bp}$ product (cpbE) $L$. infantum strains [25]. This primer pair more recently was tested, in addition to a newly designed one (cpbEF For/L.inf Rev, Table2), on 10 Tunisian L. infantum isolates. The amplification showed size polymorphism of cpbEF genes with either a 702bp or a 741bp product, even though the species $L$. donovani has never been described in Tunisia and the Mediterranean region [85]. 
Five species-specific PCR tests that can discriminate each of the Old World species: L. infantum, L. donovani, L. tropica, L. aethiopica, and L. major in cultured parasite isolates were also developed [86] (Table2). All the PCRs are based on the species-specific amplification of the cpb genes as each primer pair amplifies only one of the different cpb copies present in a particular species. In addition, the authors established the adaptation of 2 of these assays for oligochromatography detection, which is a rapid dipstick test for visualization of specific amplified $L$. infantum and $L$. donovani products. They concluded to the value of these assays for the identification of parasites in vitro but the assays were not shown sensitive enough to identify Leishmania parasites within clinical samples [86].

However, upon sequencing of the cpb- coding region in clinical isolates of L. aethiopica, specific PCR primers (V5F/V10R) were developed to differentiate this species from L. tropica, L. major, L. donovani and L. infantum by direct PCR (Table2). This cpb PCR proved to be sensitive enough to detect L. aethiopica from biopsy samples [87].

Recently, primers developed in [25] were used and new ones were designed, to set up three species-specific PCR assays based on the amplification of different copies and parts of the cpb genes (Table2) [85]. They allowed amplification of $1176 \mathrm{bp}, 600 \mathrm{bp}$ and $325 \mathrm{bp}$ fragments, thus discriminating between Old World Tunisian L. major, L. tropica and L. infantum species, respectively [85].

Multi-copy cpb genes have been recently used to develop a species-specific $L$. infantum LAMP assay (Loop-Mediated Isothermal reaction) for the diagnosis of canine leishmaniasis in Tunisia [88]. This isothermal nucleic acid amplification technique uses intrinsic properties of the enzyme (Bst DNA polymerase) for auto-strand displacement DNA synthesis to amplify large amounts of DNA within 30-60 minutes. The amplification reaction that is conducted at only one temperature does not require a thermocycler and takes profit of the intricate design of a set of six specific primers [89]. LAMP has emerged as a powerful tool for diagnostics and has been successfully developed for several protozoan parasitic diseases including leishmaniasis [90]. Use of cpb genes in the LAMP assay successfully allowed to detect the L. infantum DNA with a specific amplification, as no cross reaction was seen, with L. major, L. tropica, L. turanica, L. aethiopica, L. tarentolae, L. gerbilli, Trypanosoma cruzi, or human genomic DNA. In addition, LAMP assay showed a higher sensitivity when compared to conventional cpb based PCRs [88].

$\mathrm{Cpb}$ coding sequence and UTR targets have a proven and good potential to characterize or identify Leishmania species. Their antigenic nature makes them interesting to describe epidemiological features in some areas. However in spite of being multi-copy targets, sensitivity of their detection seem to be limited likely due to sequence variations underlying the primers used.

\subsubsection{Cytochrome gene sequencing}

Cytochromes are involved in the electron transport process of the mitochondrial respiratory chain. They are considered one of the most useful genes for taxonomy given their slow evolution rate. They were used for discrimination of Leishmania parasites as well as for exploring their phylogenetic relationships. Cytochrome oxidase II gene has been first analyzed 
for sequence variation in 22 Leishmania isolates representative of the L. donovani complex from different geographical origins [91]. Phylogenetic analysis produced maximum parsimony, neighbor joining and maximum likelihood trees that were congruent and showed two clades corresponding to the species L. donovani and L. infantum. Furthermore, the molecular haplotypes were concordant, in general, with the isoenzyme data of the complex [91]. Interestingly, L. donovani isolates from Sudan were shown to possess the most ancestral cytochrome oxidase II sequence with a single haplotype that was very close to that of L. major [91]. The data provided in this work allowed an approximate dating of the origin of the L. donovani complex to a period contemporary to or predating the spread of modern humans out of Africa [91].

Cytochrome $\mathrm{b}(\mathrm{C} y \mathrm{t} b)$ gene has also been used to determine the nucleotide sequence from 13 human-infecting Leishmania species from the New and Old Worlds [92]. The phylogenetic relationships based on this gene, showed good agreement with the classification of Lainson \& Shaw [93] except for the inclusion of L. major in the L. tropica complex and the placement of $L$. tarentolae in another genus [92]. The same group has further applied this method to other Leishmania species to construct a new phylogenic tree [94]. A total of 30 Leishmania and Endotrypanum WHO reference strains were analyzed. The phylogenic tree obtained showed mainly the exclusion of L. major from the L. tropica complex, the placement of L. tarentolae in the genus and location of L. turanica and L. arabica far from human pathogenic Leishmania strains [94].

Since that, $C y t b$ gene have been sequenced in several studies and was shown to be able to identify the Leishmania species, in Pakistan [95,96], in Colombia [97] and in China [98]. Furthermore, results of $C y t b$ gene sequencing of 69 cutaneous leishmaniasis cases in Pakistan showed that only L. tropica was found in highland areas and only L. major in lowland areas [96]. Importantly, among L. major samples analyzed, three types of $C y t b$ polymorphism were found, including 45 cases of type I, six of type II and one of type III [96]. The authors reported for the first time on the presence of polymorphisms in L. major (types I, II and III) based on species identification using Cyt $b$ gene sequencing from clinical samples [96].

This target is a slow evolving DNA molecule and is thus considered as a good marker for phylogeny. Being located on the mitochondrial maxicercle, the copy number constitutes another advantage. Given demonstration of natural genetic exchange experimentally [99] and naturally [100], these targets known to have a monoparental transmission (also confirmed for Leishmania) could be ideal for genetic exchange analyses.

\subsubsection{Other molecular tools}

Several other molecular tools have also been used for identification and characterization of Leishmania. These include quantitative PCR, AFLP, LAMP assay and others.

In recent years, quantitative PCR methods based either on SYBR Green or TaqMan technology have been set up for the quantification of Leishmania in different types of biopsies from mice, dogs and also from human peripheral blood, targeting either single-copy or multi-copy sequences with high sensitivity and reproducibility [101-104]. In particular, quantitative real time PCR assays (qPCR) were developed to detect and rapidly differentiate Leishmania species 
and also to quantify parasites within clinical samples. Primers used recognized kinetoplast minicircle [105,106] and ribosomal DNA [107].

Amplified fragment length polymorphism (AFLP) has also been developed for Leishmania typing [108]. This technique essentially probes the entire genome at random, without prior sequence knowledge. Thus, it is ideally suited as a screening tool for molecular markers linked with biological and clinical traits. It is a PCR-based technique that uses restriction enzymes to digest DNA, followed by ligation of adapters to the ends of the restriction fragments, which will be then amplified using specific primers. The amplified fragments are separated and visualised on denaturing polyacrylamide gels, through autoradiography or fluorescence methodologies or using automated capillary sequencing instruments. AFLP was adapted to the Leishmania genome and validated on a panel of samples from the L. donovani complex. Results were highly congruent with previous analyses using multiple other molecular tests [109]. AFLPs are particularly useful for assessing genetic variation and genome mapping over other existing molecular techniques (reviewed in [110]).

Assays using alternative amplification technologies such as quantitative nucleic acid sequencebased amplification (QT-NASBA) based on amplification of 18S RNA or Loop mediated isothermal amplification (LAMP) targeting rRNA, kinetoplast DNA or a multigenic family were also tested on Leishmania infected samples. QT-NASBA yielded a sensitivity of $97.5 \%$ and a specificity of $100 \%$ when tested on skin biopsy samples from Old and New World CL patients [111]. A generic loop mediated isothermal amplification (LAMP) of reverse transcribed 18SRNA had a $83 \%$ sensitivity on blood samples of VL patients from Sudan and $98 \%$ sensitivity on skin biopsies of CL patients from Suriname [90]. An L. donovani specific LAMP was developed targeting kinetoplast minicircle DNA that had $80 \%$ sensitivity on 10 blood samples of VL patients from Bengladesh [112]. This assay evaluated on a larger number of patients ( $\mathrm{N}=75$ ) and 101 negative controls had 90\% sensitivity and 100\% specificity; these performances were found comparable to a nested PCR assay tested on the same samples [113]. An $L$. infantum specific LAMP assay, targeting the cysteine protease B multi copy gene was also recently developed [88]. This tool applied on detection of dog infection in Tunisia had a sensitivity of $54 \%$ and a specificity of $80 \%$, a better performance than the one obtained with a $\mathrm{Cpb}$ PCR assay [88]. LAMP assays constitute promising tools for rapid and sensitive detection of Leishmania DNA, however for discrimination of Leishmania species and strains other tools may appear superior at this stage. Their main advantage remains the rapid delivery of results and the minimal equipment requirement.

\section{Strain typing}

\subsection{Multilocus sequence typing (MLST)}

Multilocus sequence typing (MLST) refers to analysis based on the DNA sequence of multiple gene targets. It is based on the comparison of partial sequences (usually $700 \mathrm{bp}$ ) of a defined set of housekeeping genes. Similarly to MLEE, alleles are scored as identical or not, regardless of how many different polymorphic loci they have. Strains sharing the same allele combina- 
tions for the set of genes tested are referred to as sequence types. MLST is able to detect codominant single nucleotide polymorphisms (SNP) and although indels can complicate the analysis, they are extremely rare in protein-coding genes.

The first Leishmania complex that has been studied with MLST is the L. donovani complex. Two sets of 5 loci corresponding to genes coding for enzymes used in MLEE were studied: one set with asat, gpi, nh1, nh2 and pgd and the other one with icd, me, mpi, g6pdh, and fh $[7,8]$. Results were found to be largely in agreement with the results from MLEE although some key discrepancies were found and increased resolution was obtained. Thus silent SNPs were found that provide further resolution, such as a single SNP in gpi that distinguishes between strains of L. infantum [7]. However, SNPs responsible for amino acid changes were also found in genes coding for enzymes giving indistinguishable electrophoretic profiles, mainly in nh2, which had the same protein band for all L. donovani complex strains. MLST study contributed to better understanding of $L$. donovani complex phylogeny and taxonomical position of the species $L$. infantum and L. donovani [114]. It was a strong argument to question the position of L. archibaldi as a species [6] and existence of MLEE defined L. infantum in Sudan [8]. It also highlighted potential occurrence of genetic exchange among circulating parasites in East Africa $[7,8]$.

MLST using 6 gene targets that are not associated with MLEE analysis (inorganic pyrophosphatase, spermidine synthase 1 , hypoxanthine-guanine phosphoribosyl transferase, mitogenactivated protein kinase, RNA polymerase II largest sub-unit and adenylate kinase 2) have been used to characterize suspected L. major/L. infantum hybrids and representative coendemic strains in Portugal [115]. Sequence analyses confirmed MLEE hybrid profiles and hybrid status with occurrence of heterozygous positions in the target genes that so far were not studied for their diversity within Leishmania species. In a more recent work, 2 of these genes and 5 others (Elongation initiation factor 2 alpha subunit, zinc binding dehydrogenase-like protein, translation initiation factor alpha subunit, nucleoside hydrolase-like protein and a hypothetical protein located on chromosome 31) were analyzed on a panel of 222 strains representative of 10 different species in 43 countries in Eurasia and Africa, corresponding to 110 zymodemes with the objective to study the genetic diversity of the genus Leishmania, improving our knowledge on the genetic structure and genomic evolution mechanisms of this genus [116]. Seven genetically robust clusters were obtained that overlapped with most of the biochemical taxonomy groups: clusters I, III, IV, V and VI included strains belonging to the MLEE-based species L. aethiopica, L. arabica, L. turanica, L. gerbilli and L. major, respectively and cluster II included the L. tropica and L. killicki strains; with the exception of the species that cause forms of visceral leishmaniasis (cluster VII that comprised strains from L. donovani, L. infantum and L. archibaldi) in line with the concept of species complex suggested for this group. No observations were made of interspecific recombination or genetic exchange between the different species but these strains were selected for the study as not resulting from a likely genetic exchange [116]. It is anticipated to observe more informative studies increasing the number of markers or the strains circulating within selected endemic areas notably that cosympatry of multiple parasite species is a well-established feature in many endemic areas.

In the New World, four housekeeping genes (glucose-6-phosphate dehydrogenase (G6PD), 6phosphogluconate dehydrogenase (6PGD), mannose phosphate isomerase (MPI) and isoci- 
trate dehydrogenase (ICD)) were sequenced from 96 Leishmania (Viannia) strains that were chosen to be representative of the zymodeme and geographical species diversity of this subgenus, in South America, and in particular Brazil, in order to assess their discriminatory typing capacity and refine phylogeny of the L. (Viannia) species [117]. A large number of haplotypes were detected for each marker. Maximum parsimony-based haplotype networks showed separated clusters in each network, corresponding to strains of different species, congruent with the MLEE identification. Besides, NeighborNet formed by the concatenated sequences confirmed species-specific clusters. This analysis also suggested recombination occurring in L. braziliensis and L. guyanensis. However, using phylogenetic analysis, the species L. lainsoni and L. naiffi were shown to be the most divergent species and placed the L. shawi species in the L. guyanensis cluster, not as a distinct species. The authors also found the $L$. braziliensis strains to correspond to one widely geographically distributed clonal complex in Brazil and another restricted to one endemic area, in a region bordering Peru [117].

The main advantage of MLST is the possibility of generating genus-wide phylogenies, since MLST markers are co-dominant and are amenable for population and phylogenetic analyses. Also, given the high quality of sequence data, results can be easily compared between laboratories. Compared to MLEE, MLST does not necessarily require sterile culture of parasites. In addition, simultaneous typing of reference strains and sequencing can be done commercially without in-house specialized equipment. For those reasons, MLST is likely to become the gold standard basis for taxonomy and thus identification of Leishmania. One expected drawback could be the inherent limit of detection of nucleotide allelic diversity associated to direct sequencing of PCR products, which could be overcome by more lengthy analyses like cloning of parasites or PCR products. One consequence of this drawback is that MLST should not be considered as typing tool but an analysis tool. Another application could be diagnosis as recently new species-specific genetic polymorphisms were identified in the genes that confer the phenotypic variations in the MLEE assay [118]. Indeed, sequencing of the MPI and 6PGD genes was sufficient to differentiate among closely related species causing New World leishmaniasis, in Peru. The same group took advantage of these polymorphisms and designed a new real-time PCR assay based on FRET (fluorescence resonance energy transfer) technology and melting curve analysis using SYBR green. The assay was highly sensitive and correctly identified each of the five main species that cause tegumentary leishmaniasis in the New World, directly from clinical samples [119].

\subsection{Multilocus microsatellite typing (MLMT)}

Microsatellites are repeated motives of 1-6 nucleotide(s), which present allelic length variation. They mutate fast, therefore, 10-20 independent markers have to be analyzed for each strain owing to homoplasy. Microsatellite sequence variation results from the gain and loss of repeat units, which can easily be detected after amplification with specific primers annealing to their flanking regions. Then length polymorphisms are detected using PAGE, MetaPhor agarose gel electrophoresis or, preferably, automated capillary sequencers. A multilocus microsatellite profile is compiled for each sample from the fragment length measured for the microsatellite markers analyzed. 
During the last years, microsatellite-based approaches have been developed for strain typing within the genus Leishmania to overcome the lack of discriminatory power of MLEE and other molecular tools. So far, microsatellite loci with high discriminatory power and suitable for characterizing closely related strains have been published for the L. donovani/L. infantum complex [120-122], L. major [123,124], L. tropica [125] and for species of the subgenus L. (Viannia) [126-128].

\subsubsection{Subgenus L. Leishmania}

\subsubsection{L. donovani complex}

Within the L. donovani complex, a set of 15 microsatellite markers have been applied to type strains of L. donovani and L. infantum isolated from the main endemic regions for VL (India, East Africa, Mediterranean region, Asia and South America) [129]. Six principal genetically distinct populations were identified: 2 populations of L. infantum from the Mediterranean area and South America comprising the MON-1 and non-MON-1 strains, respectively; 2 populations of L. donovani from Sudan and Ethiopia; 1 of L. donovani MON-2 from India; and 1 consisting of strains of L. donovani (MON-36, 37 and 38) from Kenya and India. These results corroborated the fragmentary data published in numerous studies using other genetic markers. Interestingly, the highest microsatellite diversity was observed for L. infantum from the Mediterranean basin and the lowest for L. donovani from India. Using 34 additional microsatellite sequences, analysis showed the homogeneity of L. donovani from the Indian subcontinent [130].

Different genetic groups of strains of L. infantum were also observed when strains from Algeria, Tunisia, the Palestinian Authority and Israel were subjected to MLMT. Microsatellite typing of strains belonging to zymodemes MON-1, MON-24 and MON-80 identified 3 different populations in Algeria and in Tunisia [131,132]. The MON-1 strains were assigned to 2 different populations one of which contained only local strains and the other local and European strains of MON-1. The non-MON-1 strains were always separated from the MON-1 ones. Gene flow was detected between the two MON-1 populations and the local MON-1 and the non-MON-1 populations, respectively [131,132]. L. infantum Israeli and Palestinian strains obtained from infected dogs and human cases showed 2 main populations genetically different from European populations, one of which is sub-divided in geographically distributed sub populations [133].

In Spain, L. infantum strains from a rural leishmaniasis-endemic area, from which 94 were obtained from dogs, 15 from sand flies, and 1 from a human visceral case, were MLMT studied [134]. Results showed existence of 17 genotypes that were detected using 10 microsatellite markers belonging to 3 different targets. They also showed the heterogeneous distribution of L. infantum species in hosts living in sympatric conditions.

Analysis of L. infantum strains having a New World origin by MLMT indicated that these strains were more similar to MON-1 and non-MON-1 sub-populations of L. infantum from southwest Europe, than to any other Old World sub-population [135] thus indicating that the parasite has been recently imported multiple times to the New World from southwest Europe. 
Within the L. donovani complex, L. donovani, L. infantum and L. archibaldi strains from Sudan were studied by MLMT technique [6]. The authors found one single monophyletic L. donova$n i$ clade and argued that the isoenzyme differentiation of L. donovani and L. infantum in East Africa was misleading and that L. archibaldi is an invalid taxon [6].

Analysis of L. donovani strains from India, Bangladesh, Sri Lanka and Nepal showed that in Sri Lanka the causative agent of CL is most closely related to parasites causing VL in India [136] and that genetically homogeneous strains are circulating in the Indian subcontinent [130]. On the other hand, L. donovani strains belonging to the MON-37 zymodeme and originating from different geographical origins (India, Sri Lanka, Middle East, Cyprus and East Africa) were MLMT analyzed [9]. Zymodeme MON-37 was found to be paraphyletic, representing different genetic groups corresponding to their geographical origin and strains from Cyprus were clearly different from all others and could be autochthonous [9].

\subsubsection{L. tropica}

MLMT technique was also applied for L. tropica strain typing. Indeed, 117 strains from Asia and Africa were used and revealed 10 genetic groups, which were largely correlated to the geographical origin of the strains [125]. Different genetic groups were shown to co-exist in strains from the Middle East and Morocco. However, the authors postulated that recent spread of new genotypes has occurred recently in the Middle East and suspected an African origin of the L. tropica species [125].

\subsubsection{L. major}

Concerning L. major, 106 strains from Central Asia, Africa and the Middle East were analyzed using MLMT, based on 10 different microsatellite markers [124]. The study showed three main populations corresponding to the three geographical regions studied that were further subdivided into 2 sub-populations. Interestingly, the African and Middle Eastern populations seemed to be more genetically diversified than the Central Asian population [124].

\subsubsection{Subgenus L. Viannia}

Within the New World L. Viannia subgenus, the first MLMT studied species were L. braziliensis and L. peruviana. Fifty- nine analyzed Peruvian strains showed emergence of multiple $L$. braziliensis/L. peruviana hybrids [137]. Then, 124 L. braziliensis strains from Peru and Bolivia were investigated for their genetic polymorphism at 12 microsatellite loci $[127,138]$. A substantial genetic diversity with high levels of inbreeding, inconsistent with a strictly clonal reproduction was shown. Besides, a large genetic heterogeneity between populations within countries was described, which evidenced a strong population structure at a microgeographic scale [138].

In another study, polymorphisms of 30 strains of L. braziliensis, 21 strains of L. guyanensis, and 2 strains of L. peruviana from Brazil, Paraguay and Peru were analyzed at 15 independent microsatellite loci [128]. All strains except two L. guyanensis had individual MLMT types. In addition, three main clades were found, that consisted of one population of strains of $L$. 
guyanensis only, another one with strains of L. braziliensis from Paraguay and Brazil, and the last one with strains of L. braziliensis and L. peruviana [128].

Recently, 28 strains of the main species of the L. guyanensis complex (L. guyanensis and L. panamensis), collected in Ecuador and Peru were investigated in an MLMT study, with 12 microsatellite markers [139]. An important heterozygote deficit was observed in these populations, similar to the previously reported results in L. braziliensis complex [138]. They further showed genetic polymorphism and geographical differentiation on the L. guyanensis complex [139].

All together, these studies confirmed that microsatellite markers constitute good tools for typing and population genetic studies of Leishmania. Their additional advantage resides in the possibility of their use directly in biological material without culturing of parasites [130,140]. Moreover, accurate, quality controlled microsatellite profiles could be stored in databases and compared between different laboratories.

\section{Leishmania parasite evolution, genetics and genome analyses - Consequences and prospects}

For many years Leishmania parasites have been considered to replicate clonally, without genetic exchange. Indeed, Tibayrenc proposed that clonal evolution in micropathogens be defined as restrained recombination on an evolutionary scale, with genetic exchange scarce enough to not break the prevalent pattern of clonal population structure (Reviewed in [141,142]). The two main manifestations of clonal evolution are strong linkage disequilibrium (LD) and widespread genetic clustering ("near-clading"). These authors hypothesized that this pattern is not mainly due to natural selection, but would originate chiefly from in-built genetic properties of pathogens, that would allow like for other microorganisms (viruses, bacteria, protozoan parasites) to keep a balance between clonality and recombination, which would help escape from recombinational load. This way, to face evolutionary challenges, pathogens would be equipped with "clonality/sexuality machinery" that would function as alternative allelic systems [141,142]. However, an accumulation of molecular evidence indicates that there are inter-specific $[115,137,143-146]$ and intra-specific $[132,138]$ hybrids among natural populations. Genetic exchange was finally demonstrated experimentally in 2009 [99]. In fact, double drug resistant Leishmania major hybrids were produced by co-infecting Phlebotomus duboscqi (a natural L. major vector) sand flies with two strains carrying different drug resistance markers. The nuclear genotypes were consistent with a Mendelian transmission leading to a heterozygous first generation progeny [99]. The anticipated continuity of these studies was to co-infect sand flies with transgenic Leishmania carrying two different markers that are fluorescent, in an attempt to visualize the recombination events microscopically [147]. In 2011, for the first time, using a fluorescent protein detection system to observe yellow hybrid promastigotes in Phlebotomus perniciosus and Lutzomyia longipalpis midguts, L. donovani hybrids were observed, 2 days post bloodmeal, and the morphological stages involved were found to be short procyclic promastigotes [100]. However, the parasites could not be recovered and propagated to confirm 
their hybrid genotypes [100]. Recently, the analysis of the mating competency of L. major strains have been expanded to include pairwise matings of multiple isolates bearing independent drug markers [148]. Also, the timing of the appearance of hybrids and their developmental stage associations within both natural (Phlebotomus duboscqi) and unnatural (Lutzomyia longipalpis) sand fly vectors was followed. Genotype analysis of a large number of progeny clones showed a chromosomal inheritance of both parental alleles at 4-6 unlinked nuclear loci, consistent with a meiotic process, and a uniparental inheritance of kinetoplast DNA [148]. A low frequency of nuclear loci showed only one parental allele, suggesting loss of heterozygosity, most likely arising from aneuploidy, which is common in Leishmania. In the natural vector, when comparing the timing of hybrid formation and the presence of developmental stages, the authors suggested that nectomonad promastigotes are the most likely mating competent forms, with hybrids emerging before the first appearance of metacyclic promastigotes [148].

MLMT analysis showed that recombination events are much more frequent in Leishmania than previously thought. Indeed, MLMT analysis of Bolivian and Peruvian L. braziliensis showed frequent sexual crosses of individuals from the same strain (inbreeding) [138]. The substantial heterozygote deficiency and extreme inbreeding found in this study is not consistent with a strictly clonal reproduction. The authors came to the conclusion that Leishmania parasites may alternate between clonal and sexual modes of reproduction, occurring most probably in the vector [138]. Sexual fusion may frequently take place between genetically related parasites or even within the same strain with occasional recombination events between individuals of different genotypes.

Also, L. braziliensis/L. peruviana hybrids were found to be quite common in a Peruvian focus where both species can occur sympatrically [137]. In the Old World, natural L. infantum/L. major hybrids were experimentally transmitted by $\mathrm{Ph}$. papatasi, usually only competent to transmit L. major [149]. This suggests that hybrids may circulate using this sand fly vector and spread into new foci throughout the broad range of Ph. papatasi distribution.

The fact that Leishmania can undergo genetic exchange is potentially of profound epidemiological significance since this could facilitate the emergence and spread of new genotypes and phenotypic traits. Also, hybrid offspring might show a strong selective advantage relative to the parental strains. In [149], the authors have shown that natural hybrids could have enhanced transmission potential and a positively affected fitness.

New high-throughput sequencing technologies have opened the door for population genome analyses and genome-wide association studies. Genome of the L. major species was the first to be fully sequenced [150] followed by L. infantum and L. braziliensis [151]. Comparison of the three genomes revealed conservation of synteny and identified only 200 genes having a differential distribution between the three species. Such genes may encode for proteins implicated in host-pathogen interactions and parasite survival in the macrophage [151]. The species L. mexicana and L. donovani were subsequently sequenced $[152,153]$ and the reference genomes for L. major, L. infantum, and L. braziliensis were refined [152]. This has allowed the identification of a remarkably low number of genes or paralog groups unique to each of the species L. mexicana, L. major, L. infantum, and L. braziliensis (2, 14, 19, and 67, respectively). Besides, L. major and L. infantum were found to have a surprisingly low number of predicted 
heterozygous SNPs compared with L. braziliensis and L. mexicana. Chromosome copy number also varied significantly between species, with nine supernumerary chromosomes in $L$. infantum, four in L. mexicana, two in L. braziliensis, and one in L. major. The authors also showed that gene duplication events occur more frequently on disomic chromosomes [152]. In addition to sequencing of an L. donovani reference genome, a recent study also included sequence analysis of a set of 16 related clinical lines, isolated from VL patients in Nepal and India, which also differ in their in vitro drug response [153]. Sequence comparisons with other Leishmania species and analysis of single-nucleotide diversity showed evidence of selection acting on different surface- and transport-related genes, including genes associated with drug resistance. Extensive variation in chromosome copy number between the analyzed lines was also shown. In association to drug resistance, they also showed structural variation, including gene dosage and copy number variation of a circular episome, present in all lines [153].

Genomic research on Leishmania is taking promising directions, mainly upon sequencing of the main pathogenic species [150-153] and also the non pathogenic L. tarentolae [154] which will enable to answer key questions on population genetics and ultimately unravel many important aspects related to drug resistance and virulence, which are especially relevant for control of the disease.

Novel genomics technologies are expected to bring more powerful tools to characterize the pathogens and particularly the infectious stages of Leishmania parasites. It will be particularly useful to fully characterize the parasites within the lesions/hosts in their microenvironment. While so far expression profiling relied mainly on microarray analysis which revealed only a limited number of differentially expressed genes across developmental stages [155], or species [156]. RNA sequencing technology seems very promising to highlight transcriptional events that are associated to parasite life cycle, infection or pathology. Previous studies have demonstrated a correlation between gene expression and gene copy number $[157,158]$. It was further hypothesized that "Increased gene copy number due to chromosome amplification may contribute to alterations in gene expression in response to environmental conditions in the host, providing a genetic basis for disease tropism" [152]. Other studies have also suggested that Leishmania parasites do not respond dynamically to host immune pressure, and that any influence of varying transcript levels on virulence and pathogenicity of the different Leishmania species is likely to result from the differential expression of conserved genes between species and/or the expression of a small number of genes that are differentially distributed between species [159].

Genome-wide multilocus genotyping in malaria research through novel sequencing technologies has allowed the identification of almost 47000 single nucleotide polymorphisms (SNPs) across the Plasmodium genome [160]. This allowed development of microarray-based platforms for screening more than 3000 SNPs that were successfully applied for population genetic analyses and genome-wide association studies in P. falciparum [161,162]. Similar studies still need to be developed for Leishmania. 


\section{Conclusion}

Epidemiological, taxonomic and population genetic studies of Leishmania require good sampling methods and appropriate molecular markers that allow discrimination at different levels. Answering key epidemiological questions requires new or improved tools that allow discrimination of Leishmania parasites at different levels. The MLEE, considered as gold standard technique, needs cultured parasites and lacks discriminatory power. PCR assays are likely to replace isoenzyme analysis since they enable direct detection and identification of different Leishmania species in human and animal samples and also in infected sand flies. Many of the PCR assays described in the literature have proven useful in numerous field studies. However, they still need to be standardized and validated as diagnostic PCR assays and comparisons of the sensitivity and specificity parameters of the different approaches need also validation under routine conditions. In general, more than one assay is necessary to obtain fully satisfactory analysis of field samples. Given emergence context and changing ecoepidemiological trends, multiple tools will be needed to fully investigate the transmitted parasites.

At the strain level differentiation, MLMT has potential for being a gold standard, because on its principle it is expected to be reproducible and brings possibility of data storage and exchange. However, microsatellite markers are largely species-specific in Leishmania and different marker sets have to be used according to species. Such databases do not exist yet and data generation will need standardization. It may also require access to automated sequencers and good knowledge of population genetics programs. On the other hand MLST appears potentially as more powerful for phylogenetic and evolutionary studies although less discriminatory than MLMT. It is most probably this technique that will advantageously replace MLEE in the future. Some results showed that the same targets could be used across the Leishmania genus, which will enable comparisons of distances between the species but also of the degree of genetic diversity within species [163]. Here also it will require access to automated sequencers and adequate analytical programs. Cost of both approaches are relatively high and inherent limitations will be most likely overcome by the next generation sequencing approaches expected to gain momentum in a near future. Leishmania population genomics still needs to be developed and made accessible to researchers in disease endemic countries to best achieve its public health potential.

Parasite knowledge is so far built on strains obtained in vitro. Increasing interest in Leishmania parasite analyses will likely identify novel genotypes or organisms, a challenge for our current knowledge on parasite taxonomy and assays to identify and characterize parasites. Improving ways to enhance knowledge on parasites within samples remains a priority.

In spite of the increasing potential of sophisticated technologies and techniques, some disease endemic areas still need simple assays for eco-epidemiological investigations or diagnosis as well as capacity building in this highly relevant area to disease control. 


\section{Acknowledgements}

Research on Leishmania Molecular diagnostics in our laboratory has received support from the Ministry of Higher Education and Scientific Research and Technology in Tunisia (BSP46, LR00SP04 \& LR11IPT04) and from different international programs: EU-Avicenne (CT920013), STD3 (CT930253), INCO-DC (CT970256); TDR-RSG (ID890266), TDR-RTG (920781), TDR-PAG (A30380); MERC-NIAID-NIH (NO1AI45183); IAEA (TUN06-12; CRP15111); CRDF (TN1-7009-TP-09); AUF (PCSI 6319PS011).

\section{Author details}

Souheila Guerbouj, Imen Mkada-Driss and Ikram Guizani

Laboratoire d'Epidemiologie et d'Ecologie Parasitaire / Epidémiologie Moléculaire et Pathologie Expérimentale Appliquée (Leishmania Genomics and Genetics Program), Institut Pasteur de Tunis, Université Tunis el Manar, Tunisia

The number of references for this review has been restricted by space restraints. The authors apologize to the authors whose work was not cited in this review.

\section{References}

[1] Lainson R, Shaw JJ. New World leishmaniasis-the neotropical Leishmania species. In: Cox FEG, Kreier JP, Wakelin D, editors. Topley \& Wilson's Microbiology and Microbial Infections. London: Arnold; 1998.

[2] Sacks DL, Kenney RT, Kreutzer RD, Jaffe CL, Gupta AK, Sharma MC, et al. Indian kala-azar caused by Leishmania tropica. Lancet. 1995 Apr 15;345(8955):959-61.

[3] Alvar J, Vélez ID, Bern C, Herrero M, Desjeux P, Cano J, et al.; WHO Leishmaniasis Control Team. Leishmaniasis worldwide and global estimates of its incidence. PLoS One. 2012;7(5):e35671.

[4] Guizani I, Mukhtar M, Alvar J, Ben Abderrazak S, Shaw J. (2011) Leishmaniases. In: Nriagu JO, editor. Encyclopedia of Environmental Health, volume 3, pp. 453-480. Burlington: Elsevier; 2011.

[5] Schönian G, Mauricio I, Gramiccia M, Cañavate C, Boelaert M, Dujardin JC. Leishmaniases in the Mediterranean in the era of molecular epidemiology. Trends Parasitol. 2008 Mar;24(3):135-42.

[6] Jamjoom MB, Ashford RW, Bates PA, Chance ML, Kemp SJ, Watts PC, et al. Leishmania donovani is the only cause of visceral leishmaniaisis in East Africa; previous de- 
scriptions of L. infantum and "L. archibaldi" from this region are a consequence of convergent evolution in the isoenzyme data. Parasitology. 2004 Oct;129(Pt 4):399-409.

[7] Mauricio IL, Yeo M, Baghaei M, Doto D, Pratlong F, Zemanova E, et al. Towards multilocus sequence typing of the Leishmania donovani complex: resolving genotypes and haplotypes for five polymorphic metabolic enzymes (ASAT, GPI, NH1, NH2, PGD). Int J Parasitol. 2006 Jun;36(7):757-69.

[8] Zemanová E, Jirků M, Mauricio IL, Horák A, Miles MA, Lukes J. The Leishmania donovani complex: genotypes of five metabolic enzymes (ICD, ME, MPI, G6PDH, and FH), new targets for multilocus sequence typing. Int J Parasitol. 2007 Feb;37(2):149-60.

[9] Alam MZ, Haralambous C, Kuhls K, Gouzelou E, Sgouras D, Soteriadou K, et al. The paraphyletic composition of Leishmania donovani zymodeme MON-37 revealed by multilocus microsatellite typing. Microbes Infect. 2009 May-Jun;11(6-7):707-15.

[10] Van Eys GJ, Schoone GJ, Kroon NC, Ebeling SB. Sequence analysis of small subunit ribosomal RNA genes and its use for detection and identification of Leishmania parasites. Mol Biochem Parasitol. 1992 Mar;51(1):133-42.

[11] Lachaud L, Marchergui-Hammami S, Chabbert E, Dereure J, Dedet JP, Bastien P. Comparison of six PCR methods using peripheral blood for detection of canine visceral leishmaniasis. J Clin Microbiol. 2002 Jan;40(1):210-5.

[12] Schönian G, Nasereddin A, Dinse N, Schweynoch C, Schallig HD, Presber W, et al. PCR diagnosis and characterization of Leishmania in local and imported clinical samples. Diagn Microbiol Infect Dis. 2003 Sep;47(1):349-58.

[13] Bensoussan E, Nasereddin A, Jonas F, Schnur LF, Jaffe CL. Comparison of PCR assays for diagnosis of cutaneous leishmaniasis. J Clin Microbiol. 2006 Apr;44(4):1435-9.

[14] Nicolas L, Prina E, Lang T, Milon G. Real-time PCR for detection and quantitation of leishmania in mouse tissues. J Clin Microbiol. 2002 May;40(5):1666-9.

[15] Schulz A, Mellenthin K, Schönian G, Fleischer B, Drosten C. Detection, differentiation, and quantitation of pathogenic leishmania organisms by a fluorescence resonance energy transfer-based real-time PCR assay. J Clin Microbiol. 2003 Apr;41(4): 1529-35.

[16] Cupolillo E, Grimaldi Júnior G, Momen H, Beverley SM. Intergenic region typing (IRT): a rapid molecular approach to the characterization and evolution of Leishmania. Mol Biochem Parasitol. 1995 Jul;73(1-2):145-55.

[17] Nasereddin A, Bensoussan-Hermano E, Schönian G, Baneth G, Jaffe CL. Molecular diagnosis and species identification of Old World cutaneous leishmaniasis using a reverse line blot hybridization assay. J Clin Microbiol. 2008 Sep;46(9):2848-55. 
[18] Harris E, Kropp G, Belli A, Rodriguez B, Agabian N. Single-step multiplex PCRassay for characterization of NewWorld Leishmania complexes. J Clin Microbiol. 1998 Jul; 36(7):1989-95.

[19] Marfurt J, Niederwieser I, Makia ND, Beck HP, Felger I. Diagnostic genotyping of Old and New World Leishmania species by PCR-RFLP. Diagn Microbiol Infect Dis. 2003 Jun;46(2):115-24.

[20] Victoir K, Bañuls AL, Arevalo J, Llanos-Cuentas A, Hamers R, Noël S, et al. The gp63 gene locus, a target for genetic characterization of Leishmania belonging to subgenus Viannia. Parasitology. 1998 Jul;117(Pt 1):1-13.

[21] Guerbouj S, Victoir K, Guizani I, Seridi N, Nuwayri-Salti N, Belkaid M, et al. Gp63 gene polymorphism and population structure of Leishmania donovani complex: influence of the host selection pressure? Parasitology. 2001 Jan;122(Pt 1):25-35.

[22] Garcia L, Kindt A, Bermudez H, Llanos-Cuentas A, De Doncker S, Arevalo J, et al. Culture-independent species typing of neotropical Leishmania for clinical validation of a PCR-based assay targeting heat shock protein 70 genes. J Clin Microbiol. 2004 May;42(5):2294-7.

[23] Fraga J, Montalvo AM, De Doncker S, Dujardin JC, Van der Auwera G. Phylogeny of Leishmania species based on the heat-shock protein 70 gene. Infect Genet Evol. 2010 Mar;10(2):238-45.

[24] Da Silva LA, de Sousa Cdos S, da Graça GC, Porrozzi R, Cupolillo E. Sequence analysis and PCR-RFLP profiling of the hsp70 gene as a valuable tool for identifying Leishmania species associated with human leishmaniasis in Brazil. Infect Genet Evol. 2010 Jan;10(1):77-83.

[25] Hide M, Bañuls AL. Species-specific PCR assay for L. infantum/L. donovani discrimination. Acta Trop. 2006 Dec;100(3):241-5.

[26] Oshaghi MA, Ravasan NM, Hide M, Javadian EA, Rassi Y, Sedaghat MM, et al. Development of species-specific PCR and PCR-restriction fragment length polymorphism assays for L.infantum/L. donovani discrimination. Exp Parasitol. 2009 May; 122(1):61-5.

[27] Williams JG, Kubelik AR, Livak KJ, Rafalski JA, Tingey SV. DNA polymorphisms amplified by arbitrary primers are useful as genetic markers. Nucleic Acids Res. 1990 Nov 25;18(22):6531-5.

[28] Schriefer AL, Góes-Neto A, Guimarães LH, Carvalho LP, Almeida RP, et al. Multiclonal Leishmania braziliensis population structure and its clinical implication in a region of endemicity for American tegumentary leishmaniasis. Infect Immun. 2004 Jan; 72(1):508-14. 
[29] Gomes RF, Macedo AM, Pena SD, Melo MN. Leishmania (Viannia) braziliensis: genetic relationships between strains isolated from different areas of Brazil as revealed by DNA fingerprinting and RAPD. Exp Parasitol. 1995 Jun;80(4):681-7.

[30] Motazedian H, Noyes H, Maingon R. Leishmania and Sauroleishmania: the use of random amplified polymorphic DNA for the identification of parasites from vertebrates and invertebrates. Exp Parasitol. 1996 Jun;83(1):150-4.

[31] Manna M, Majumder HK, Sundar S, Bhaduri AN. The molecular characterization of clinical isolates from Indian Kala-azar patients by MLEE and RAPD-PCR. Med Sci Monit. 2005 Jul;11(7):BR220-7.

[32] Carvalho Mde L, de Andrade AS, Fontes CJ, Hueb M, de Oliveira Silva S, Melo MN. Leishmania (Viannia) braziliensis is the prevalent species infecting patients with tegumentary leishmaniasis from Mato Grosso State, Brazil. Acta Trop. 2006 Jul;98(3): 277-85.

[33] Noyes HA, Belli AA, Maingon R. Appraisal of various random amplified polymorphic DNA-polymerase chain reaction primers for Leishmania identification. Am J Trop Med Hyg. 1996 Jul;55(1):98-105.

[34] Hanafi R, Barhoumi M, Ali SB, Guizani I. Molecular analyses of Old World Leishmania RAPD markers and development of a PCR assay selective for parasites of the L. donovani species Complex. Exp Parasitol. 2001 Jun;98(2):90-9.

[35] Diakou A, Dovas CI. Optimization of random-amplified polymorphic DNA producing amplicons up to $8500 \mathrm{bp}$ and revealing intraspecies polymorphism in Leishmania infantum isolates. Anal Biochem. 2001 Jan 15;288(2):195-200.

[36] Guizani I, Dellagi K, Ismaïl RB. Random amplified polymorphic DNA technique for identification and differentiation of Old World Leishmania species. Am J Trop Med Hyg. 2002 Feb;66(2):152-6.

[37] Bañuls AL, Guerrini F, Le Pont F, Barrera C, Espinel I, Guderian R, et al. Evidence for hybridization by multilocus enzyme electrophoresis and random amplified polymorphic DNA between Leishmania braziliensis and Leishmania panamemsis/ guyanensis in Ecuador. J Eukaryot Microbiol. 1997 Sep-Oct;44(5):408-11.

[38] Bañuls AL, Jonquieres R, Guerrini F, Le Pont F, Barrera C, Espinel I, et al. Genetic analysis of Leishmania parasites in Ecuador : are Leishmania (Viannia) panamensis and Leishmania (V.) guyanensis distinct taxa ? Am J Trop Med Hyg. 1999 Nov;61(5): 838-45.

[39] Mauricio IL, Howard MK, Stothard JR, Miles MA. Genomic diversity in the Leishmania donovani complex. Parasitology. 1999 Sep;119 ( Pt 3):237-46.

[40] Rioux JA, Lanotte G, Serres E, Pratlong F, Bastien P, Perieres J. Taxonomy of Leishmania. Use of isoenzymes. Suggestions for a new classification. Ann Parasitol Hum Comp. 1990;65(3):111-25. 
[41] Zemanová E, Jirků M, Mauricio IL, Miles MA, Lukes J. Genetic polymorphism within the Leishmania donovani complex: correlation with geographic origin. Am J Trop Med Hyg. 2004 Jun;70(6):613-7.

[42] Toledo A, Martín-Sánchez J, Pesson B, Sanchiz-Marín C, Morillas-Márquez F. Genetic variability within the species Leishmania infantum by RAPD. A lack of correlation with zymodeme structure. Mol Biochem Parasitol. 2002 Feb;119(2):257-64.

[43] Hide M, Bañuls AL, Tibayrenc M. Genetic heterogeneity and phylogenetic status of Leishmania (Leishmania) infantum zymodeme MON-1: epidemiological implications. Parasitology. 2001 Nov;123(Pt 5):425-32.

[44] Segatto M, Ribeiro LS, Costa DL, Costa CH, Oliveira MR, Carvalho SF, et al. Genetic diversity of Leishmania infantum field populations from Brazil. Mem Inst Oswaldo Cruz. 2012 Feb;107(1):39-47.

[45] Cupolillo E, Brahim LR, Toaldo CB, de Oliveira-Neto MP, de Brito ME, Falqueto A, et al. Genetic polymorphism and molecular epidemiology of Leishmania (Viannia) braziliensis from different hosts and geographic areas in Brazil. J Clin Microbiol. 2003 Jul; 41(7):3126-32.

[46] Khanra S, Bandopadhyay SK, Chakraborty P, Datta S, Mondal D, Chatterjee M, et al. Characterization of the recent clinical isolates of Indian Kala-azar patients by RAPDPCR method. J Parasit Dis. 2011 Oct;35(2):116-22.

[47] Khanra S, Datta S, Mondal D, Saha P, Bandopadhyay SK, Roy S, et al. RFLPs of ITS, ITS1 and hsp70 amplicons and sequencing of ITS1 of recent clinical isolates of Kalaazar from India and Bangladesh confirms the association of L. tropica with the disease. Acta Trop. 2012 Dec;124(3):229-34.

[48] Mahmoudzadeh-Niknam H, Ajdary S, Riazi-Rad F, Mirzadegan E, Rezaeian A, Khaze V, et al. Molecular epidemiology of cutaneous leishmaniasis and heterogeneity of Leishmania major strains in Iran. Trop Med Int Health. 2012 Nov;17(11):1335-44.

[49] Martinez E, Alonso V, Quispe A, Thomas MC, Alonso R, Piñero JE, González AC, Ortega A, Valladares B. RAPD method useful for distinguishing Leishmania species: design of specific primers for L. braziliensis. Parasitology. 2003 Dec;127(Pt 6):513-7.

[50] Lewin S, Schönian G, El Tai N, Oskam L, Bastien P, Presber W. Strain typing in Leishmania donovani by using sequence-confirmed amplified region analysis. Int J Parasitol. 2002 Sep;32(10):1267-76.

[51] Mkada-Driss I, Lahmadi R, Chakroun AS, Talbi C, Elamin EM, Cupollilo E, et al. Screening and characterization of RAPD polymorphic markers in viscerotropic Leishmania parasites. In preparation.

[52] Mkada-Driss I, Talbi C, Elamin EM, Lahmadi R, Bakhiet S, Fathallah-Mili A, et al. Simple DNA assays for molecular epidemiology of visceral leishmaniasis in Africa: 
development and evaluation of species and countries specific PCR assays. In preparation.

[53] Mauricio IL, Gaunt MW, Stothard JR, Miles MA. Glycoprotein 63 (gp63) genes show gene conversion and reveal the evolution of Old World Leishmania. Int J Parasitol. 2007 Apr;37(5):565-76.

[54] Guerbouj S, Chamekh L, Jlassi M, Jbir R, Guizani I. Genetic polymorphism of Tunisian Leishmania infantum species by restriction analysis of PCR amplified gp63 and PSA2 coding genes. Personal communication.

[55] BenSaid M, Guerbouj S, Saghrouni F, Fathallah-Mili A, Guizani I. Occurrence of Leishmania infantum cutaneous leishmaniasis in central Tunisia. Trans $R$ Soc Trop Med Hyg. 2006 Jun;100(6):521-6.

[56] Elamin EM, Guerbouj S, Musa AM, Guizani I, Khalil EA, Mukhtar MM, et al. Uncommon clinical presentations of cutaneous leishmaniasis in Sudan. Trans $R$ Soc Trop Med Hyg. 2005 Nov;99(11):803-8.

[57] Elamin EM, Guizani I, Guerbouj S, Gramiccia M, El Hassan AM, Di Muccio T, et al. Identification of Leishmania donovani as a cause of cutaneous leishmaniasis in Sudan. Trans R Soc Trop Med Hyg. 2008 Jan;102(1):54-7.

[58] Mauricio IL, Gaunt MW, Stothard JR, Miles MA. Genetic typing and phylogeny of the Leishmania donovani complex by restriction analysis of PCR amplified gp63 intergenic regions. Parasitology. 2001 Apr;122(Pt 4):393-403.

[59] Al-Jawabreh A, Schnur LF, Nasereddin A, Schwenkenbecher JM, Abdeen Z, Barghuthy $\mathrm{F}$, et al. The recent emergence of Leishmania tropica in Jericho (A'riha) and its environs, a classical focus of L. major. Trop Med Int Health. 2004 Jul;9(7):812-6.

[60] Rhajaoui M, Nasereddin A, Fellah H, Azmi K, Amarir F, Al-Jawabreh A, et al. New clinico-epidemiologic profile of cutaneous leishmaniasis, Morocco. Emerg Infect Dis. 2007 Sep;13(9):1358-60.

[61] Kuhls K, Mauricio IL, Pratlong F, Presber W, Schönian G. Analysis of ribosomal DNA internal transcribed spacer sequences of the Leishmania donovani complex. Microbes Infect. 2005 Aug-Sep;7(11-12):1224-34.

[62] Talmi-Frank D, Nasereddin A, Schnur LF, Schönian G, Töz SO, Jaffe CL, et al. Detection and identification of Old World Leishmania by high resolution melt analysis. PLoS Negl Trop Dis. 2010 Jan 12;4(1):e581.

[63] De Almeida ME, Steurer FJ, Koru O, Herwaldt BL, Pieniazek NJ, da Silva AJ. Identification of Leishmania spp. by molecular amplification and DNA sequencing analysis of a fragment of rRNA internal transcribed spacer 2. J Clin Microbiol. 2011 Sep;49(9): 3143-9.

[64] El Tai NO, Osman OF, el Fari M, Presber W, Schönian G. Genetic heterogeneity of ribosomal internal transcribed spacer in clinical samples of Leishmania donovani 
spotted on filter paper as revealed by single-strand conformation polymorphisms and sequencing. Trans R Soc Trop Med Hyg. 2000 Sep-Oct;94(5):575-9.

[65] El Tai NO, El Fari M, Mauricio I, Miles MA, Oskam L, El Safi SH, et al. Leishmania donovani: intra-specific polymorphisms of Sudanese isolates revealed by PCR-based analyses and DNA sequencing. Exp Parasitol. 2001 Jan;97(1):35-44.

[66] Schönian G, Schnur L, el Fari M, Oskam L, Kolesnikov AA, Sokolowska-Köhler W, et al. Genetic heterogeneity in the species Leishmania tropica revealed by different PCR-based methods. Trans R Soc Trop Med Hyg. 2001 Mar-Apr;95(2):217-24.

[67] Schönian G, El Fari M, Lewin S, Schweynoch C, Presber W. Molecular epidemiology and population genetics in Leishmania. Med Microbiol Immunol. 2001 Nov;190(1-2): 61-3.

[68] Tashakori M, Kuhls K, Al-Jawabreh A, Mauricio IL, Schönian G, Farajnia S, et al. Leishmania major: genetic heterogeneity of Iranian isolates by single-strand conformation polymorphism and sequence analysis of ribosomal DNA internal transcribed spacer. Acta Trop. 2006 Apr;98(1):52-8.

[69] Ghatee M, Sharifi I, Mirhendi H, Kanannejad Z, Hatam G. Investigation of DoubleBand Electrophoretic Pattern of ITS-rDNA Region in Iranian Isolates of Leishmania tropica. Iran J Parasitol. 2013 Apr;8(2):264-72.

[70] Hartl FU, Hayer-Hartl M. Molecular chaperones in the cytosol: from nascent chain to folded protein. Science. 2002 Mar 8;295(5561):1852-8.

[71] Folgueira C, Requena JM. A postgenomic view of the heat shock proteins in kinetoplastids. FEMS Microbiol Rev. 2007 Jul;31(4):359-77.

[72] Montalvo AM, Fraga J, Monzote L, Montano I, De Doncker S, Dujardin JC, et al. Heat-shock protein 70 PCR-RFLP: a universal simple tool for Leishmania species discrimination in the New and Old World. Parasitology. 2010 Jul;137(8):1159-68.

[73] Montalvo AM, Fraga J, Maes I, Dujardin JC, Van der Auwera G. Three new sensitive and specific heat-shock protein 70 PCRs for global Leishmania species identification. Eur J Clin Microbiol Infect Dis. 2012 Jul;31(7):1453-61.

[74] Fraga J, Montalvo AM, Maes L, Dujardin JC, Van der Auwera G. HindII and SduI digests of heat-shock protein 70 PCR for Leishmania typing. Diagn Microbiol Infect Dis. 2013 Nov;77(3):245-7.

[75] Fraga J, Veland N, Montalvo AM, Praet N, Boggild AK, Valencia BM, et al. Accurate and rapid species typing from cutaneous and mucocutaneous leishmaniasis lesions of the New World. Diagn Microbiol Infect Dis. 2012 Oct;74(2):142-50.

[76] Van der Auwera G, Maes I, De Doncker S, Ravel C, Cnops L, Van Esbroeck M, et al. Heat-shock protein 70 gene sequencing for Leishmania species typing in European tropical infectious disease clinics. Euro Surveill. 2013 Jul 25;18(30):20543. 
[77] Requena JM, Chicharro C, García L, Parrado R, Puerta CJ, Cañavate C. Sequence analysis of the 3'-untranslated region of HSP70 (type I) genes in the genus Leishmania: its usefulness as a molecular marker for species identification. Parasit Vectors. 2012 Apr 28;5:87.

[78] Serin MS, Waki K, Chang KP, Aslan G, Direkel S, Otag F, et al. Consistence of miniexon polymerase chain reaction-restriction fragment length polymorphism and singlecopy gene sequence analyses in discriminating Leishmania genotypes. Diagn Microbiol Infect Dis. 2007 Mar;57(3):295-9.

[79] Marfurt J, Nasereddin A, Niederwieser I, Jaffe CL, Beck HP, Felger I. Identification and differentiation of Leishmania species in clinical samples by PCR amplification of the miniexon sequence and subsequent restriction fragment length polymorphism analysis. J Clin Microbiol. 2003 Jul;41(7):3147-53.

[80] Serin MS, Daglioglu K, Bagirova M, Allahverdiyev A, Uzun S, Vural Z, et al. Rapid diagnosis and genotyping of Leishmania isolates from cutaneous and visceral leishmaniasis by microcapillary cultivation and polymerase chain reaction-restriction fragment length polymorphism of miniexon region. Diagn Microbiol Infect Dis. 2005 Nov;53(3):209-14.

[81] Pandey K, Yanagi T, Pandey BD, Mallik AK, Sherchand JB, Kanbara H. Characterization of Leishmania isolates from Nepalese patients with visceral leishmaniasis. Parasitol Res. 2007 May;100(6):1361-9.

[82] Roelfsema JH, Nozari N, Herremans T, Kortbeek LM, Pinelli E. Evaluation and improvement of two PCR targets in molecular typing of clinical samples of Leishmania patients. Exp Parasitol. 2011 Jan;127(1):36-41.

[83] Quispe Tintaya KW, Ying X, Dedet JP, Rijal S, De Bolle X, Dujardin JC. Antigen genes for molecular epidemiology of leishmaniasis: polymorphism of cysteine proteinase $B$ and surface metalloprotease glycoprotein 63 in the Leishmania donovani complex. J Infect Dis. 2004 Mar 15;189(6):1035-43.

[84] Seridi N, Belkaid M, Quispe-Tintaya W, Zidane C, Dujardin JC. Application of PCRRFLP for the exploration of the molecular diversity of Leishmania infantum in Algeria. Trans R Soc Trop Med Hyg. 2008 Jun;102(6):556-63.

[85] Chaouch M, Fathallah-Mili A, Driss M, Lahmadi R, Ayari C, Guizani I, et al. Identification of Tunisian Leishmania spp. by PCR amplification of cysteine proteinase B (cpb) genes and phylogenetic analysis. Acta Trop. 2013 Mar;125(3):357-65.

[86] Laurent T, Van der Auwera G, Hide M, Mertens P, Quispe-Tintaya W, Deborggraeve $\mathrm{S}$, et al. Identification of Old World Leishmania spp. by specific polymerase chain reaction amplification of cysteine proteinase B genes and rapid dipstick detection. $\mathrm{Di}$ agn Microbiol Infect Dis. 2009 Feb;63(2):173-81. 
[87] Kuru T, Janusz N, Gadisa E, Gedamu L, Aseffa A. Leishmania aethiopica: development of specific and sensitive PCR diagnostic test. Exp Parasitol. 2011 Aug;128(4): 391-5.

[88] Chaouch M, Mhadhbi M, Adams ER, Schoone GJ, Limam S, Gharbi Z, et al. Development and evaluation of a loop-mediated isothermal amplification assay for rapid detection of Leishmania infantum in canine leishmaniasis based on cysteine protease B genes. Vet Parasitol. 2013 Nov 15;198(1-2):78-84.

[89] Notomi T, Okayama H, Masubuchi H, Yonekawa T, Watanabe K, Amino N, et al. Loop-mediated isothermal amplification of DNA. Nucleic Acids Res. 2000 Jun 15;28(12):E63.

[90] Adams ER, Schoone GJ, Ageed AF, Safi SE, Schallig HD. Development of a reverse transcriptase loopo-mediated isothermal amplification (LAMP) assay for the sensitive detection of Leishmania parasites in clinical samples. Am J Trop Med Hyg. 2010 Apr;82(4):591-6.

[91] Ibrahim ME, Barker DC. The origin and evolution of the Leishmania donovani complex as inferred from a mitochondrial cytochrome oxidase II gene sequence. Infect Genet Evol. 2001 Jul;1(1):61-8.

[92] Luyo-Acero GE, Uezato H, Oshiro M, Takei K, Kariya K, Katakura K, et al. Sequence variation of the cytochrome $b$ gene of various human infecting members of the genus Leishmania and their phylogeny. Parasitology. 2004 May;128(Pt 5):483-91.

[93] Lainson R, Shaw JJ. Evolution, classification and geographical distribution. In: Peters W, Killick-Kendrick R, editors. The Leishmaniasis in Biology and Medicine. Vol. I Biology and Epidemiology. Orlando, USA: Orlando Academic Press; 1987.

[94] Asato Y, Oshiro M, Myint CK, Yamamoto Y, Kato H, Marco JD, et al. Phylogenic analysis of the genus Leishmania by cytochrome b gene sequencing. Exp Parasitol. 2009 Apr;121(4):352-61.

[95] Marco JD, Bhutto AM, Soomro FR, Baloch JH, Barroso PA, Kato H, et al. Multilocus enzyme electrophoresis and cytochrome $\mathrm{B}$ gene sequencing-based identification of Leishmania isolates from different foci of cutaneous leishmaniasis in Pakistan. Am J Trop Med Hyg. 2006 Aug;75(2):261-6.

[96] Myint CK, Asato Y, Yamamoto Y, Kato H, Bhutto AM, Soomro FR, et al. Polymorphisms of cytochrome $\mathrm{b}$ gene in Leishmania parasites and their relation to types of cutaneous leishmaniasis lesions in Pakistan. J Dermatol. 2008 Feb;35(2):76-85.

[97] Martínez LP, Rebollo JA, Luna AL, Cochero S, Bejarano EE. Molecular identification of the parasites causing cutaneous leishmaniasis on the Caribbean coast of Colombia. Parasitol Res. 2010 Feb;106(3):647-52.

[98] Yang BB, Chen DL, Chen JP, Liao L, Hu XS, Xu JN. Analysis of kinetoplast cytochrome $b$ gene of 16 Leishmania isolates from different foci of China: different spe- 
cies of Leishmania in China and their phylogenetic inference. Parasit Vectors. 2013 Feb $5 ; 6: 32$.

[99] Akopyants NS, Kimblin N, Secundino N, Patrick R, Peters N, Lawyer P, et al. Demonstration of genetic exchange during cyclical development of Leishmania in the sand fly vector. Science 2009 Apr 10;324(5924):265-8.

[100] Sadlova J, Yeo M, Seblova V, Lewis MD, Mauricio I, Volf P, et al. Visualisation of Leishmania donovani fluorescent hybrids during early stage development in the sand fly vector. PLoS One. 2011;6(5):e19851.

[101] Lombardo G, Pennisi MG, Lupo T, Migliazzo A, Caprì A, Solano-Gallego L. Detection of Leishmania infantum DNA by real-time PCR in canine oral and conjunctival swabs and comparison with other diagnostic techniques. Vet Parasitol. 2012 Feb 28;184(1):10-7.

[102] Da Silva RN, Amorim AC, Brandão RM, de Andrade HM, Yokoo M, Ribeiro ML, et al. Real-time PCR in clinical practice: a powerful tool for evaluating Leishmania chagasi loads in naturally infected dogs. Ann Trop Med Parasitol. 2010 Mar;104(2):137-43.

[103] De Paiva Cavalcanti M, Felinto de Brito ME, de Souza WV, de Miranda Gomes Y, Abath FG. The development of a real-time PCR assay for the quantification of Leishmania infantum DNA in canine blood. Vet J. 2009 Nov;182(2):356-8.

[104] Antinori S, Calattini S, Piolini R, Longhi E, Bestetti G, Cascio A, et al. Is real-time polymerase chain reaction (PCR) more useful than a conventional PCR for the clinical management of leishmaniasis? Am J Trop Med Hyg. 2009 Jul;81(1):46-51.

[105] Weirather JL, Jeronimo SM, Gautam S, Sundar S, Kang M, Kurtz MA, et al. Serial quantitative PCR assay for detection, species discrimination, and quantification of Leishmania spp. in human samples. J Clin Microbiol. 2011 Nov;49(11):3892-904.

[106] Jara M, Adaui V, Valencia BM, Martinez D, Alba M, Castrillon C, et al. Real-time PCR assay for detection and quantification of Leishmania (Viannia) organisms in skin and mucosal lesions: exploratory study of parasite load and clinical parameters. J Clin Microbiol. 2013 Jun;51(6):1826-33.

[107] De Paiva Cavalcanti M, Dantas-Torres F, da Cunha Gonçalves de Albuquerque S, Silva de Morais RC, de Brito ME, Otranto D, et al. Quantitative real time PCR assays for the detection of Leishmania (Viannia) braziliensis in animals and humans. Mol Cell Probes. 2013 Jun-Aug;27(3-4):122-8.

[108] Kumar A, Boggula VR, Misra P, Sundar S, Shasany AK, Dube A. Amplified fragment length polymorphism (AFLP) analysis is useful for distinguishing Leishmania species of visceral and cutaneous forms. Acta Trop. 2010 Feb;113(2):202-6.

[109] Odiwuor S, Vuylsteke M, De Doncker S, Maes I, Mbuchi M, Dujardin JC, et al. Leishmania AFLP: paving the way towards improved molecular assays and markers of diversity. Infect Genet Evol. 2011 Jul;11(5):960-7. 
[110] Kumar A, Misra P, Dube A. Amplified fragment length polymorphism: an adept technique for genome mapping, genetic differentiation, and intraspecific variation in protozoan parasites. Parasitol Res. 2013 Feb;112(2):457-66.

[111] Van der Meide WF, Schoone GJ, Faber WR, Zeegelaar JE, de Vries HJ, Ozbel Y, et al. Quantitative nucleic acid sequence-based assay as a new molecular tool for detection and quantification of Leishmania parasites in skin biopsy samples. J Clin Microbiol. 2005 Nov;43(11):5560-6.

[112] Takagi H, Itoh M, Islam MZ, Razzaque A, Ekram AR, Hashighuchi Y, et al. Sensitive, specific, and rapid detection of Leishmania donovani DNA by loop-mediated isothermal amplification. Am J Trop Med Hyg. 2009 Oct;81(4):578-82.

[113] Khan MG, Bhaskar KR, Salam MA, Akther T, Pluschke G, Mondal D. Diagnostic accuracy of loop-mediated isothermal amplification (LAMP) for detection of Leishmania DNA in buffy coat from visceral leishmaniasis patients. Parasit Vectors. 2012 Dec 3;5:280.

[114] Lukes J, Mauricio IL, Schönian G, Dujardin JC, Soteriadou K, Dedet JP, et al. Evolutionary and geographical history of the Leishmania donovani complex with a revision of current taxonomy. Proc Natl Acad Sci U S A. 2007 May 29;104(22):9375-80.

[115] Ravel C, Cortes S, Pratlong F, Morio F, Dedet JP, Campino L. First report of genetic hybrids between two very divergent Leishmania species: Leishmania infantum and Leishmania major. Int J Parasitol. 2006 Nov;36(13):1383-8.

[116] El Baidouri F, Diancourt L, Berry V, Chevenet F, Pratlong F, Marty P, et al. Genetic structure and evolution of the Leishmania genus in Africa and Eurasia: what does MLSA tell us. PLoS Negl Trop Dis. 2013 Jun 13;7(6):e2255.

[117] Boité MC, Mauricio IL, Miles MA, Cupolillo E. New insights on taxonomy, phylogeny and population genetics of Leishmania (Viannia) parasites based on multilocus sequence analysis. PLoS Negl Trop Dis. 2012;6(11):e1888.

[118] Tsukayama P, Lucas C, Bacon DJ. Typing of four genetic loci discriminates among closely related species of New World Leishmania. Int J Parasitol. 2009 Feb;39(3): 355-62.

[119] Tsukayama P, Núñez JH, De Los Santos M, Soberón V, Lucas CM, Matlashewski G, et al. A FRET-based real-time PCR assay to identify the main causal agents of New World tegumentary leishmaniasis. PLoS Negl Trop Dis. 2013;7(1):e1956.

[120] Bulle B, Millon L, Bart JM, Gállego M, Gambarelli F, Portús M, et al. Practical approach for typing strains of Leishmania infantum by microsatellite analysis. J Clin Microbiol. 2002 Sep;40(9):3391-7.

[121] Jamjoom MB, Ashford RW, Bates PA, Kemp SJ, Noyes HA. Towards a standard battery of microsatellite markers for the analysis of the Leishmania donovani complex. Ann Trop Med Parasitol. 2002 Apr;96(3):265-70. 
[122] Ochsenreither S, Kuhls K, Schaar M, Presber W, Schönian G. Multilocus microsatellite typing as a new tool for discrimination of Leishmania infantum MON-1 strains. J Clin Microbiol. 2006 Feb;44(2):495-503.

[123] Jamjoom MB, Ashford RW, Bates PA, Kemp SJ, Noyes HA. Polymorphic microsatellite repeats are not conserved between Leishmania donovani and Leishmania major. Molecular Ecology Notes. 2002 June;2(2):104-6.

[124] Al-Jawabreh A, Diezmann S, Müller M, Wirth T, Schnur LF, Strelkova MV, et al. Identification of geographically distributed subpopulations of Leishmania (Leishmania) major by microsatellite analysis. BMC Evol Biol. 2008 Jun 24;8:183.

[125] Schwenkenbecher JM, Wirth T, Schnur LF, Jaffe CL, Schallig H, Al-Jawabreh A, et al. Microsatellite analysis reveals genetic structure of Leishmania tropica. Int J Parasitol. 2006 Feb;36(2):237-46.

[126] Russell R, Iribar MP, Lambson B, Brewster S, Blackwell JM, Dye C, et al. Intra and inter-specific microsatellite variation in the Leishmania subgenus Viannia. Mol Biochem Parasitol. 1999 Sep 20;103(1):71-7.

[127] Rougeron V, Waleckx E, Hide M, DE Meeûs T, Arevalo J, Llanos-Cuentas A, et al. PERMANENT GENETIC RESOURCES: A set of 12 microsatellite loci for genetic studies of Leishmania braziliensis. Mol Ecol Resour. 2008 Mar;8(2):351-3.

[128] Oddone R, Schweynoch C, Schönian G, de Sousa Cdos S, Cupolillo E, Espinosa D, et al. Development of a multilocus microsatellite typing approach for discriminating strains of Leishmania (Viannia) species. J Clin Microbiol. 2009 Sep;47(9):2818-25.

[129] Kuhls K, Keilonat L, Ochsenreither S, Schaar M, Schweynoch C, Presber W, et al. Multilocus microsatellite typing (MLMT) reveals genetically isolated populations between and within the main endemic regions of visceral leishmaniasis. Microbes Infect. 2007 Mar;9(3):334-43.

[130] Alam MZ, Kuhls K, Schweynoch C, Sundar S, Rijal S, Shamsuzzaman AK, et al. Multilocus microsatellite typing (MLMT) reveals genetic homogeneity of Leishmania donovani strains in the Indian subcontinent. Infect Genet Evol. 2009 Jan;9(1):24-31.

[131] Seridi N, Amro A, Kuhls K, Belkaid M, Zidane C, Al-Jawabreh A, et al. Genetic polymorphism of Algerian Leishmania infantum strains revealed by multilocus microsatellite analysis. Microbes Infect. 2008 Oct;10(12-13):1309-15.

[132] Chargui N, Amro A, Haouas N, Schönian G, Babba H, Schmidt S, et al. Population structure of Tunisian Leishmania infantum and evidence for the existence of hybrids and gene flow between genetically different populations. Int J Parasitol. 2009 Jun; 39(7):801-11.

[133] Amro A, Schönian G, Al-Sharabati MB, Azmi K, Nasereddin A, Abdeen Z, et al. Population genetics of Leishmania infantum in Israel and the Palestinian Authority through microsatellite analysis. Microbes Infect. 2009 Apr;11(4):484-92. 
[134] Montoya L, Gállego M, Gavignet B, Piarroux R, Rioux JA, Portús M, et al. Application of microsatellite genotyping to the study of a restricted Leishmania infantum focus: different genotype compositions in isolates from dogs and sand flies. Am J Trop Med Hyg. 2007 May;76(5):888-95.

[135] Kuhls K, Alam MZ, Cupolillo E, Ferreira GE, Mauricio IL, Oddone R, et al. Comparative microsatellite typing of new world leishmania infantum reveals low heterogeneity among populations and its recent old world origin. PLoS Negl Trop Dis. 2011 Jun; 5(6):e1155.

[136] Siriwardana HV, Noyes HA, Beeching NJ, Chance ML, Karunaweera ND, Bates PA. Leishmania donovani and cutaneous leishmaniasis, Sri Lanka. Emerg Infect Dis. 2007 Mar;13(3):476-8.

[137] Nolder D, Roncal N, Davies CR, Llanos-Cuentas A, Miles MA. Multiple hybrid genotypes of Leishmania (Viannia) in a focus of mucocutaneous leishmaniasis. Am J Trop Med Hyg. 2007 Mar;76(3):573-8.

[138] Rougeron V, De Meeûs T, Hide M, Waleckx E, Bermudez H, Arevalo J, et al. Extreme inbreeding in Leishmania braziliensis. Proc Natl Acad Sci U S A. 2009 Jun 23;106(25): 10224-9.

[139] Rougeron V, De Meeûs T, Hide M, Waleckx E, Dereure J, Arevalo J, et al. A battery of 12 microsatellite markers for genetic analysis of the Leishmania (Viannia) guyanensis complex. Parasitology. 2010 Nov;137(13):1879-84.

[140] Alam MZ, Kovalenko DA, Kuhls K, Nasyrova RM, Ponomareva VI, Fatullaeva AA, et al. Identification of the agent causing visceral leishmaniasis in Uzbeki and Tajiki foci by analysing parasite DNA extracted from patients' Giemsa-stained tissue preparations. Parasitology. 2009 Aug;136(9):981-6.

[141] Tibayrenc M, Ayala FJ. Reproductive clonality of pathogens: a perspective on pathogenic viruses, bacteria, fungi, and parasitic protozoa. Proc Natl Acad Sci U S A. 2012 Nov 27;109(48):E3305-13.

[142] Tibayrenc M, Ayala FJ. How clonal are Trypanosoma and Leishmania? Trends Parasitol. 2013 Jun;29(6):264-9.

[143] Delgado O, Cupolillo E, Bonfante-Garrido R, Silva S, Belfort E, Grimaldi Júnior G, et al. Cutaneous leishmaniasis in Venezuela caused by infection with a new hybrid between Leishmania (Viannia) braziliensis and L. (V.) guyanensis. Mem Inst Oswaldo Cruz. 1997 Sep-Oct;92(5):581-2.

[144] Dujardin JC, Banuls AL, Llanos-Cuentas A, Alvarez E, DeDoncker S, Jacquet D, et al. Putative Leishmania hybrids in the Eastern Andean valley of Huanuco, Peru. Acta Trop. 1995 Aug;59(4):293-307. 
[145] Belli AA, Miles MA, Kelly JM. A putative Leishmania panamensis/Leishmania braziliensis hybrid is a causative agent of human cutaneous leishmaniasis in Nicaragua. Parasitology. 1994 Nov;109 (Pt 4):435-42.

[146] Kelly JM, Law JM, Chapman CJ, Van Eys GJ, Evans DA. Evidence of genetic recombination in Leishmania. Mol Biochem Parasitol. 1991 Jun;46(2):253-63.

[147] Miles MA, Yeo M, Mauricio IL. Genetics. Leishmania exploit sex. Science. 2009 Apr 10;324(5924):187-9.

[148] Inbar E, Akopyants NS, Charmoy M, Romano A, Lawyer P, Elnaiem DE, et al. The mating competence of geographically diverse Leishmania major strains in their natural and unnatural sand fly vectors. PLoS Genet. 2013 Jul;9(7):e1003672.

[149] Volf P, Benkova I, Myskova J, Sadlova J, Campino L, Ravel C. Increased transmission potential of Leishmania major/Leishmania infantum hybrids. Int J Parasitol. 2007 May;37(6):589-93.

[150] Ivens AC, Peacock CS, Worthey EA, Murphy L, Aggarwal G, Berriman M, et al. The genome of the kinetoplastid parasite, Leishmania major. Science. $2005 \mathrm{Jul}$ 15;309(5733):436-42.

[151] Peacock CS, Seeger K, Harris D, Murphy L, Ruiz JC, Quail MA, et al. Comparative genomic analysis of three Leishmania species that cause diverse human disease. Nat Genet. 2007 Jul;39(7):839-47.

[152] Rogers MB, Hilley JD, Dickens NJ, Wilkes J, Bates PA, Depledge DP, et al. Chromosome and gene copy number variation allow major structural change between species and strains of Leishmania. Genome Res. 2011 Dec;21(12):2129-42.

[153] Downing T, Imamura H, Decuypere S, Clark TG, Coombs GH, Cotton JA, et al. Whole genome sequencing of multiple Leishmania donovani clinical isolates provides insights into population structure and mechanisms of drug resistance. Genome Res. 2011 Dec;21(12):2143-56.

[154] Raymond F, Boisvert S, Roy G, Ritt JF, Légaré D, Isnard A, et al. Genome sequencing of the lizard parasite Leishmania tarentolae reveals loss of genes associated to the intracellular stage of human pathogenic species. Nucleic Acids Res. 2012 Feb;40(3): 1131-47.

[155] Srividya G, Duncan R, Sharma P, Raju BV, Nakhasi HL, Salotra P. Transcriptome analysis during the process of in vitro differentiation of Leishmania donovani using genomic microarrays. Parasitology. 2007 Oct;134(Pt 11):1527-39.

[156] Rochette A, Raymond F, Ubeda JM, Smith M, Messier N, Boisvert S, et al. Genomewide gene expression profiling analysis of Leishmania major and Leishmania infantum developmental stages reveals substantial differences between the two species. BMC Genomics. 2008 May 29;9:255. 
[157] Ubeda JM, Légaré D, Raymond F, Ouameur AA, Boisvert S, Rigault P, et al. Modulation of gene expression in drug resistant Leishmania is associated with gene amplification, gene deletion and chromosome aneuploidy. Genome Biol. 2008;9(7):R115.

[158] Leprohon P, Légaré D, Raymond F, Madore E, Hardiman G, Corbeil J, et al. Gene expression modulation is associated with gene amplification, supernumerary chromosomes and chromosome loss in antimony-resistant Leishmania infantum. Nucleic Acids Res. 2009 Apr;37(5):1387-99.

[159] Depledge DP, Evans KJ, Ivens AC, Aziz N, Maroof A, Kaye PM, et al. Comparative expression profiling of Leishmania: modulation in gene expression between species and in different host genetic backgrounds. PLoS Negl Trop Dis. 2009 Jul 7;3(7):e476.

[160] Volkman SK, Sabeti PC, DeCaprio D, Neafsey DE, Schaffner SF, Milner DA Jr, et al. A genome-wide map of diversity in Plasmodium falciparum. Nat Genet. 2007 Jan;39(1): $113-9$.

[161] Neafsey DE, Schaffner SF, Volkman SK, Park D, Montgomery P, Milner DA Jr, et al. Genome-wide SNP genotyping highlights the role of natural selection in Plasmodium falciparum population divergence. Genome Biol. 2008;9(12):R171.

[162] Mu J, Myers RA, Jiang H, Liu S, Ricklefs S, Waisberg M, et al. Plasmodium falciparum genome-wide scans for positive selection, recombination hot spots and resistance to antimalarial drugs. Nat Genet. 2010 Mar;42(3):268-71.

[163] Miles MA, Llewellyn MS, Lewis MD, Yeo M, Baleela R, Fitzpatrick S, et al. The molecular epidemiology and phylogeography of Trypanosoma cruzi and parallel research on Leishmania: looking back and to the future. Parasitology. 2009 Oct;136(12): 1509-28. 
